\title{
FROM RŪM TO TOKYO: THE SEARCH FOR ANTICOLONIAL ALLIES BY THE RULERS OF RIAU, 1899-1914*
}

\author{
Barbara Watson Andaya
}

Japan's admittance of foreign trade after 1854 and the dramatic reforms of the Meiji Restoration brought a relatively unknown country to the attention of the international community. In the ensuing decades, European statesmen, initially skeptical of Japanese efforts towards modernization, came to recognize that any formulation of diplomatic policy in the Far East must take Japan into account. A somewhat similar reappraisal of the balance of world power can be found in Asia, where the rise of Japan created for anticolonial leaders the possibility of aid from a fellow Asian nation in the struggle against foreign domination. Yet in comparison with countries such as China, India, Korea, Vietnam, and the Philippines, 1 it seems that the Indonesian archipelago regarded the achievement of Japan almost with indifference. ${ }^{2}$ However, a closer examination of specific areas in the Netherlands Indies would undoubtedly show that here, too, Japan's emergence into prominence was noted and its significance assessed.

It should not be assumed, however, that this reaction was simply a paler version of what occurred in neighboring Asian countries, and

*This article is a revised version of a paper originally presented to the First Australian Asian Studies Conference, held at Melbourne University in May, 1976. Benedict R. O'G. Anderson, Heather Sutherland, Christopher Gray, David Sissons, David Marr, Leonard Andaya, and Craig Reynolds read earlier drafts, and I am most grateful for their helpful comments and constructive criticism. I would also like to express my gratitude for an informative correspondence with Professor Akira Nagazumi.

${ }^{1}$ Ian $\mathrm{H}$. Nish, The Anglo-Japanese AlZiance: The Diplomacy of Two Is Zand Empires (London: Athlone Press, 1966), p. 23; Marius B. Jansen, The Japanese and Sun Yat Sen (Cambridge, Mass.: Harvard University Press, 1954); Josefa M. Sanie1, Japan and the Philippines, 1868-1898 (Quezon City: University of the Philippines Press, 1963); David Marr, Vietnamese Anti-Colonialism, 1885-1925 (Los Angeles: University of California Press, 1971), pp. 61, 99-112; Percival Spear, A History of India (Baltimore: Penguin, 1965), 2, p. 181; C. I. Eugene Kim and Han-kyo Kim, Korea and the Politics of Imperialism, 1876-1910 (Berkeley: University of California Press, 1967), pp. 41-42.

2J. D. Thijs, De Invioed van de Opkomst van Japan en van de Japanse Overwinning op Rusland in Azië, Public Lecture, Vrije Universiteit, Amsterdam, March 26, 1965 (Kampen: Kok, 1965), pp. 6-15. Bernhard Dahm, Sukamo and the Struggle for Indonesian Independence (Ithaca: Cornel1 University Press, 1969), p. 112, dates the Javanese response to Japan from about 1920, but Akira Nagazumi has seen it developing much earlier. See Nagazumi's article, "An Indonesian's View of Japan: Wahidin and the Russo-Japanese War," in F. H. King (ed.), The Development of Japanese Studies in Southeast Asia (Hong Kong: Centre of Asian Studies, University of Hong Kong, 1969), pp. $72-84$. 
research into local politics in the years immediately after the RussoJapanese war may well reveal identifiable differences in the origin and nature of the response in various regions of the Netherlands Indies. In the Malay kingdoms under Dutch control, for instance, expectations of Japan were most clearly voiced not by a rising generation of nationalists but among the established Moslem elites, men who had seen their prestige steadily eroded by a government which was not only alien but kafir (infide1). Priding themselves on their Islamic heritage, regarding themselves as an integral segment of a wider Moslem brotherhood, they and their forebears had traditionally looked to the Middle East for leadership and guidance. ${ }^{3}$ Their willingness now to regard Japan as a mentor and protector points to an expansion of the traditional weltanschauung which through the centuries had helped to define Malay society, and in which Japan had had no place. As elsewhere in Asia, the changed view of Japan reflected a new sense of being orang timur (Easterners/Orientals) as opposed to the orang barat (Westerners/Occidentals); but in the Malay case the acceptance of an "Asianism" shared with Japan was facilitated because it had already been acknowledged by the Islamic community at large. Without such sanction, the appeal of Japan would have been infinitely weaker.

\section{Political Background to Nineteenth Century Riau}

The evolution of this identification with Japan can be illustrated by events in the Kingdom of Riau, named for its principal island, situated about forty miles from Singapore. Two centuries earlier, Riau, then known as Johor, had been the most powerful Malay state in the archipelago, 4 but by the end of the nineteenth century there was little to attest to its former greatness. An act of regicide in 1699 brought about a period of turmoil which had changed the very nature of the polity. Johor's newly founded dynasty fell an easy victim to Minangkabau invaders and was only reestablished in 1722 with the assistance of outsiders, a group of migrant Bugis from Sulawesi (Celebes). In return for this help, the title of Yamtuan Muda (Deputy Ruler) was granted to the Bugis leader and to his descendants in perpetuity.5 Despite local Malay opposition to the increasing power assumed by the Bugis, the capital on the island of Riau flourished throughout the eighteenth century, remaining a principal entrepot on the traditional sea route from India to China. ${ }^{6}$

3I am aware that I am using the term Middle East anachronistically, since it was only coined in 1902 by an American naval historian. Malays themselves had no specific word for the Islamic heartland, that is, the lands of predominantly Persian, Arabic, and Turkish speech. Perhaps the nearest equivalent would be the phrase adopted from Persian navigators, "negeri diatas angin" (the lands to the windward of the southwest monsoon), i.e., Arabia, Persia, and India. For a discussion of the adoption of the term "Middle East," see Bernard Lewis, The Middle East and the West (London: Weidenfeld and Nicolson, 1964), pp. 16-17.

${ }^{4}$ See Leonard Y. Andaya, The Kingdom of Johor, 1641-1728: Economic and Political Developments (Kuala Lumpur: Oxford University Press, 1975), Chs. 1-4. In the nineteenth century the name Johor was used to refer to the peninsular state under the rule of the old Temenggong family.

${ }^{5}$ This is obviously a very inadequate summary of a complex series of events. For a detailed analysis of the period, see Andaya, The Kingdom of Johor, Chs. 6-10.

'Dianne Lewis, "The Growth of the Country Trade to the Straits of Malacca, 
Both Malays and Europeans of that era would have found it difficult to imagine that this thriving port would become a quiet backwater, but an unsuccessfu1 Johor attack on Dutch-controlled Melaka in 1784 marked the prelude to a continuous decline as the kingdom fell increasingly under Dutch power. The so-called London Treaty of 1824 , dividing Johor's territories between Britain and the Netherlands, was followed by another contract in 1830 which formalized Dutch protection over what was now termed the Sultanate of Riau-Lingga. ${ }^{7}$ The once-mighty kingdom now comprised only a small area on the east coast of Sumatra, the sparsely inhabited islands which spread from Singapore to the South China Sea, and the Riau-Lingga archipelago itself. Riau's decline was further emphasized by the prosperity and proximity of Singapore, which rapidly eclipsed Riau as the most important trading center in the region. The contrast between the two ports, which had already struck an English observer in 1847,8 was even more marked by the turn of the century. Henri Borel, a Dutch official who visited Riau in 1902, felt as if he were in exile, amid a quietness so oppressive that it was deathlike. In Singapore, by comparison, the streets were filled with a variety and excitement which, for Borel, epitomized the "Great Life."9

Increasing Dutch intervention in court politics also accentuated the extent to which Riau had lost control over its own destiny. For example, in 1857, the Malay ruler was abruptly deposed and replaced by his uncle, a prince not of fully royal birth. ${ }^{10}$ But more far reaching in its ramifications was Batavia's failure to appoint a new Yamtuan Muda in 1899, following the death of the old man who had held the position for forty years. Up to this time the Dutch had supported the existence of the post because they considered it a useful counterweight to the Malay Sultan. But in the meantime, extensive intermarriage between the royal families meant that the number of princes of "pure" blood, whether Bugis or Malay, had dwindled rapidly. In 1884, a raja of mixed descent, Abdul Rahman, had ascended the Riau throne; and to the Dutch, the old division between a "Malay" Sultan and a "Bugis" Yamtuan Muda seemed an artificial, cumbersome anomaly. Since the designated heir, Raja Ali Kelana, had already expressed a reluctance to succeed, 1899 was considered a convenient time to broach the idea of abolishing the post altogether.11

1760-1777," Journal of the Malaysian Branch of the Royal Asiatic Society (henceforth JMBRAS), 43, 2 (1970), pp. 114-30.

7For further details, see E. Netscher, "De Nederlanders in Djohor en Siak," Verhandelingen van het Bataviaasch Genootschap van Kunsten en Wetenschappen, 35 (1870), pp. 166-294.

8. T. Thomson, "A Glance at Rhio," Journal of the Indian Archipelago and Eastern Asia, 1 (1847), pp. 68-74.

${ }^{9} \mathrm{Henri}$ Bore1, Wi.jsheid en Schoonheid uit Indië (Amsterdam: Van Kampen, 1905), pp. 4-41. See also C. W. J. Wenneker, "Van Batavia naar Riau via Singapore," Berichten uit NederZandsch Oost Indië voor de Leden van den Sint CLaverbond, 1 (1902), p. 4.

10Netscher, "De Nederlanders," pp. 298-308; Virginia Matheson, "Mahmud, Sultan of Riau and Lingga (1823-1864)," Indonesia, 13 (April 1972), pp. 119-46; Raja Ali Haji, Tuhfat al-Nafis (Singapore: Malaysia Publications, 1965), p. 22.

${ }^{11}$ Verbaal (henceforth V), February 20, 1901, $w^{38}$, Govt. Sec. to Resident Hoogkamer of Riau, October 18, 1899; Hoogkamer to. Gov. Gen., June 18, 1899. (A11 archival references are from the Department of Internal Affairs, The Hague). Raja Ali never 
Despite the complicated genealogical links between Bugis and Malay royalty, and the disappearance of the Bugis language as well as most Bugis customs, those princes who could claim Bugis blood continued to feel a close affinity and were keenly aware of their cultural inheritance. The ties of kinship binding them together were accentuated by the fact that the majority of them lived near the Yamtuan Muda's residence on the island of Penyengat, 12 just offshore from the Dutch administrative center of Tanjung Pinang. It was on Penyengat in 1866 that the famous scholar and theologian, Raja Ali Haji (ca. 1809-ca. 1870) had completed his Tuhfat al-Nafis, the epic tale of the fortunes of his Bugis ancestors in the Malay world. A principal concern of this work was a justification of the Bugis presence in Riau, namely that in 1722 they had come to the aid of the Malay ruler when all others had failed him. The office of Yamtuan Muda, bestowed upon the Bugis leader, was a symbol of the great services they had rendered and tangible proof that they had earned their high place in Riau society. 13 Understandably, then, the Penyengat princes greeted the Dutch announcement in September 1900 , that henceforth no Yamtuan Muda would be appointed, with resentment and anger. ${ }^{14}$

Hostility to the Dutch was intensified by the pervasive Islamic atmosphere in Riau and by the "Bugis" princes' domination of Riau's religious leadership. Since the eighteenth century they had been renowned for their patronage of visiting ulama, and successive Yamtuan Muda had personally promoted the reformist ideas which swept through the Moslem world in the wake of the Wahăbì movement.15 In the $1890 \mathrm{~s}$

spelled out his reasons for refusing the post, but the Dutch assumed he wished to devote more time to his business activities.

12Penyengat had been given by a former Sultan to his Bugis wife, the sister of the Yamtuan Muda, in about 1805. Most of the Bugis princes moved there, while the Malay court was maintained on Lingga. In 1899, Sultan Abdul Rahman also moved to Penyengat. Raja Ali Haji, Tuhfat, pp. 255, 267; Koloniaal Verslag: Bijlagen Verslag der Handelingen van de Tweede Kamer der Staten Generaal, 1900-1901 (The Hague: Nijhoff, 1900), p. 31 .

${ }^{13}$ Andaya, The Kingdom of Johor, p. 8; Virginia Matheson, "The Tuhfat a1-Nafis: Structure and Sources," Bijdragen tot de taal-, Land-en volkenkunde (henceforth $B K I), 127,3$ (1971), pp. 388-90.

$14 \mathrm{~V}$ February 4, 1905, $\mathrm{A}^{4}$, Resident de Kanter of Riau to Gov. Gen., November 9, 1903. The strongly voiced objections of an earlier Resident, A. L. van Hasselt, who left Riau in 1896, were overruled. See E. B. Kielstra, "Nederland's Betrekkingen tot Riau," Onze Eeww, 12 (1912), p. 206.

${ }^{15}$ For example, Yamtuan Muda Raja Haji Abdullah (1857-58) was for many years the murshid, or director, of the Nakshahbandiyyah tarekat (mystical order) which had strong connections with Turkey and was particularly influential in fostering more exclusive Islamic attitudes. According to the Tuhfat al-Nafis, all the Penyengat princes belonged to the Nakshahbandiyyah. Raja Ali Haji, Tuhfat, pp. 350, 369. See also Anthony Reid, "Nineteenth Century Pan-Islam in Indonesia and Malaysia," Journal of Asian Studies, 26, 2 (1967), p. 273; J. Spencer Trimingham, The Sufi Orders in Islam (Oxford: Clarendon Press, 1971), pp. 74, 130; Christine Dobbin, "Islamic Revivalism in Minangkabau at the Turn of the Nineteenth Century," Modern Asian Studies, 8,3 (1974), pp. 325-26. It is interesting to note the similarities with the situation in Banten, also a strongly Islamic area. In Banten, however, the religious elite lacked political status, and the secular elite had lost touch with the Muslim 
an islamic study club, the Persekutuan Rushdiyyah, was established on Penyengat as a forum for debate on Islamic issues and a medium for disseminating religious treatises. ${ }^{16}$ Most of the princes of Bugis descent were members, and, not surprising1y, the Rushdiyyah Club became a focus for anti-Dutch feeling.

One of the prominent club leaders was Raja Ali Haji's son, Raja Khalid Hasan, generally known as Raja Hitam. Like his father, Raja Hitam saw the increasing intrusions of the West as dangerous to the health of the Moslem community, and he was militantly opposed to the Dutch presence in Riau. In his capacity as royal scribe he wielded considerable authority in court circles, and at times the Sultan turned to him for advice. ${ }^{17}$ Even more important was the leadership given by Raja Ali Kelana, Raja Hitam's third cousin and half-brother to the Sultan. Raja Ali's refusal to accept the Yamtuan Muda position had precipitated the furor of 1899 , but despite his lack of any formal office he remained, in the words of the Resident, "a man of great influence in government affairs."18 As the great-grandson of the legendary Bugis hero, Raja Haji, he could claim an especially prestigious ancestry; ${ }^{19}$ he was also highly respected by Malays, not only in Riau and Singapore, but all along the Sumatran coast, for his religious learning, his interest in promoting education--and his business acumen. Raja Ali owned fifteen houses in Singapore, as well as his own residence, had coconut plantations on several islands, controlled a number of mining concessions, and operated two steamships which plied between Singapore and Riau carrying passengers and goods.20

community. See Sartono Kartodirdjo, The Peasants' Revolt of Banten in 1888: Its Conditions, Course and Sequel. A Case Study of Social Movements in Indonesia (The Hague: De Nederlandsche Boek- en Steendrukkerij v/h Smits, 1966), pp. 61, 94.

${ }^{16}$ For a discussion of the strongly Islamic atmosphere which prevailed in Riau during this period, see Barbara Watson Andaya and Virginia Matheson, "Islamic Thought and Malay Tradition: The Writings of Raja Ali Haji of Riau (ca. 1809-ca. 1870)," presented to a colloquium on Southeast Asian Perceptions of the Past held at the Australian National University, Canberra, in February 1976. An example of a publication by the Rushdiyyah Club is Risāla al-fawa'id al-wäfiyat fì sharh ma na al-tahiyyat, a translation done by the Club members of an Arabic work by the Mecca teacher Said al-Syarif Abdullah, which deals with commentaries on the meaning of the tahiyyat prayer (Penyengat: Rushdiyyah Club, 1894). The arrangements for the celebrations at the end of the fasting month in 1896 were also published by the Rushdiyyah Club under the title Taman Penghiburan, iaitu berita kesukaan pada hari idul fitri yang diadakan oleh lid-lid Rushdiyyah Kelub (Riau: Rushdiyyah Club, 1896).

17V February 10, 1911, $\mathrm{Y}^{3}$, Note by Resident de Bruyn Kops of Riau, Bijlage M, Secret, February 2, 1903; V February 4, 1905, $A^{4}$, Resident de Kanter of Riau to Gov. Gen., February 29, 1904 , fo. 6 .

$18 \mathrm{~V}$ February 20, 1901, $\mathrm{W}^{38}$, Resident Hoogkamer to Gov. Gen., June 18, 1899; V February 4, 1905, A ${ }^{4}$, Resident de Lanoy of Riau to Gov. Gen., December 22, 1902.

${ }^{19}$ Raja Haji, regarded as a living saint (keramat hidup) even in his own lifetime, was Yamtuan Muda from 1777 to 1784 , and was killed during a Bugis attack on Dutch Melaka. See Netscher, "De Nederlanders," pp. 167-69, for a brief description of Raja Haji's life.

${ }^{20} \mathrm{~V}$ February 20, 1901, $\mathrm{W}^{38}$, Political Report on Riau, fo. 3; V February 4, 1905, Kab. Litt. A ${ }^{42}$, Govt. Sec. to Political. Agent and Consul-General at Cairo and to Consul of Netherlands at Jeddah, November 19, 1904; V February 10, 1911, $\mathrm{Y}^{3}$, Note 
Raja Ali's Singapore interests were exceptional only in their variety and extent, for although the Riau princes frowned morally on the activities of the Westernized Malays of Singapore and peninsular Johor, they still felt the powerful pull of that more cosmopolitan society.21 A number of them maintained modest residences in singapore which they visited frequently, and many traded extensively with Singapore merchants. At the level of the common man, too, there was daily interaction, since Riau's fish and copra were dependent on Singapore markets, and most of the goods found in Riau's shops were transported directly from Singapore by boat.

The constant coming and going, the ever-deepening connection between these two worlds, was crucial in shaping Riau politics during the period under discussion, for it enabled the Islamic leaders on Riau to keep in close touch with new developments in Moslem thought. After the opening of the Suez Canal in 1869, Singapore was only two weeks from Port Said by steamship, and thus it became a major embarkation point for the pilgrimage, a vital link in an international network of Islamic communication. Here Moslems from all over the Indonesian archipelago met to begin the haj to the holy city, and here they returned to share thoughts on their experiences in the Middle East.22 A striking feature of the time was the swiftness with which ideas propounded in Cairo's al-Azhar University, or discussed in a Mecca market, reached the archipelago's Moslem community. It was on this exchange of information--sometimes remarkably accurate, sometimes simply wild rumor--that Riau's understanding of world politics was based.

\section{Riau in the Islamic World}

In the reviving Islamic climate of the nineteenth century, the classical division of the world into Dār al-Islām, the House of Submission, and Dār al-Harb, the House of War (infidel lands), between which perpetual conflict was ordained, seemed very relevant. The crumbling of the Ottoman Empire in Europe and North Africa and its humiliating defeat in the Russo-Turkish War of 1877-78 highlighted an apparently general Moslem retreat before the advance of the Christian nations. The search for the causes of Islam's weakness in relation to the West became the great preoccupation of reflective Moslems. For many, notably the Turkish Sultan Abdul Hamid (1876-1909), the answer 1ay in a revitalization of the idea of Pan-Islam, a worldwide Islamic community which would unite under his leadership and drive back the infidels. Throughout his reign, this concept was actively propagated in the Middle Eastern press, by palace spokesmen, and among influential propagandists such as Jamal al-Din al-Afghani.23

by Resident de Bruyn Kops of Riau, December 28, 1910; V January 30, 1912, 41, Advisor for Native Affairs to Director of Justice, May 3, 1911. Raja Ali was involved in the establishment of a modern religious school in Singapore, and wrote several articles on education in the Malay journal al-Iman. See below, n. 85 .

$21 \mathrm{~V}$ February 4, 1905, $\mathrm{A}^{4}$, Resident de Kanter to Gov. Gen., July 27, 1904; Snouck Hurgronje to Gov. Gen:, May 7, 1904.

22w. R. Roff, The Origins of Malay Nationalism (Kuala Lumpur: University of Malaya Press, 1967), Ch. 2.

${ }^{23}$ See, for example, Lewis, The Middle East and the West, pp. 101-14; Mohamed 
The Malay areas of the Netherlands Indies were particularly receptive to such suggestions, for the Ottoman Sultanate had long been regarded with special veneration. In stories and legends the "Raja Rüm" was depicted as a mighty king who inhabited a magical land, possessing untold wealth and exerting unlimited power. ${ }^{24}$ For centuries successive rulers of Rum had been engaged in unremitting warfare against the infidels and, despite temporary advances by the unbelievers, the ottoman Sultan "is yet, and remains, the king of all the kings on earth."25 Recognition of Abdul Hamid as Islam's champion came naturally to those who, like Raja Hitam's father, Raja Ali Haji, had seen the Crimean War as a jihad, a holy war waged against kafir forces.26 Beginning in the middle of the century the religious character of anti-Dutch disturbances in south and east Sumatra had become more pronounced; in 1855 the Sultan of Jambi had actually succeeded in lodging an appeal with the Ottoman Sultan, asking for documents declaring him to be a Turkish vassal, which would enable him to resist Dutch demands. Local Moslem feeling had also been aroused by European attacks on the Turkish empire. In 1867, for instance, Malay-language pamphlets were distributed in Singapore advocating Islamic unity in opposition to European aggression in the Balkans.27 Sultan Abdul Hamid's fervor, especially his singling out of the Netherlands as Islam's bete noire, infused new spirit into a traditional conception of the world; during the prolonged Dutch-Aceh war (1873-1903), Turkey's imminent intervention was widely anticipated within the Moslem community. 28

Aboulkhir Zaki, "Modern Muslim Thought in Egypt and Its Impact on Islam in Malaya" (Ph.D. thesis, University of London, 1965), pp. 1-33; Deliar Noer, The Modernist MosZem Movement in Indonesia (Kuala Lumpur: Oxford University Press, 1973), p. 28.

${ }^{24}$ This attitude reflected Turkish dominance of the Middle East from the eleventh to the sixteenth century. See Anthony Reid, "Sixteenth Century Turkish Influence in Western Indonesia," Journal of Southeast Asian History, 10, 3 (1969), pp. 395-414; Kassim Ahmad (ed.), Hikayat Hang Thah (Kuala Lumpur: Dewan Bahasa, 1971), pp. 437-77; Abdullah Hj. Musa Lubis (ed.), Kesah Raja Marong Mahowangsa (Kuala Lumpur: Pustaka Antara, 1965), pp. 17-69; Teuku Iskandar (ed.), "De Hikajat Atjeh," Verhandelingen van het Koninklijk Instituut voor Taal-, Land- en Volkenkunde, 26 (1958), p. 167.

${ }^{25} \mathrm{C}$. Snouck Hurgronje, "Jong Turkije, Herinneringen uit Stamboe1, 25 July-23 September 1908," Verspreide Geschriften (Bonn: Kurt Schroeder, 1924), 3, p. 230.

${ }^{26}$ Handschrift 420 , Koninklijk Instituut voor Taal-, Land-en Volkenkunde, Leiden; "Memorie van Overgave" by E. Netscher, 1870. fo. 12. See also E. S. de Klerk, History of the Netherlands East Indies (Amsterdam: Israel, 1938, 1975), 2, p. 334; and Kartodirdjo, The Peasants' Revolt of Banten, p. 142. The term Turkey, though used among Europeans from the thirteenth century, was not adopted by Turks themselves until 1923. For the greater part of the nineteenth century there was no real sense of nationhood, and even the term ottoman was associated with a dynasty rather than a nation. Turks thought of themselves principally as Moslems, and as subjects of the Ottoman Sultan. "Turkey" is used here for the sake of convenience. See Bernard Lewis, The Emergence of Modern Turkey (London: Oxford University Press, 1968), pp. 1-3.

27Reid, "Nineteenth Century Pan-Islam," pp. 273-74, 281.

28Ibid., pp. 274-83. The Turkish appeal appears to have been much more muted in the peninsular Malay states, although in 1892 it was alleged that a certain Arab had toured the southern states asking the chiefs to sign a document requesting Turkish assistance in ousting the British. It was to. this Arab's actions that the Pahang disturbances of that year were attributed. Roff, The Origins of Malay Nationalism, p. 71, n. 52 . 
The sympathy of the Riau court for the Acehnese cause was well known, and many Penyengat princes would surely have supported the declaration of jihad against the Dutch proposed to them by certain Singapore Moslems. 29 To engage in such an undertaking was obviously impossible for Riau, now under tight Dutch control, but the court continued to be heartened by the idea, fostered by the Turkish Consul-General in Batavia, Muhammad Kiamil Bey $(1897-99)$, of a united Islamic brotherhood.

Kiamil's transfer to Singapore in $1904^{30}$ coincided with increasing resentment on Penyengat as it became apparent that the Dutch were adamant in their refusal to appoint another Yamtuan Muda. Raja Ali Kelana had been especially shaken by this decision. Although he himself had declined the position, he had always assumed that some other prince of suitable descent would be chosen in his stead. The Bugis princes' anger had been exacerbated by several new regulations which they considered further slights to Riau's prestige.31 Since the colonial government seemed deaf to all protests, the Riau princes, recognizing their own impotence, had decided that only one path lay open-the despatch of an envoy to the Raja Rūm. In ear1y February 1904, therefore, at a secret gathering in Raja Ali's house, it had been agreed that a letter should be sent to the Turkish Sultan. This letter would declare that, since Riau was a Moslem kingdom, it requested Turkish help to ensure that the position of Raja Muda be restored. ${ }^{32}$

Kiamil's arrival in Singapore provided the Riau court with additional impetus. During the following months a meeting was arranged with Kiamil in Singapore, ${ }^{33}$ and over $\$ 20,000$ (Singapore) was raised to finance the mission to Turkey. In October, Raja Ali left for the Middle East, carrying with him a number of letters from the royal archives as well as the Dutch treaty made with Riau at the time of the ruler's deposition in 1857.34 As far as Dutch agents could ascertain,

29Reid, "Nineteenth Century Pan-Islam," p. 276. Riau was about 83 percent Moslem, with the remaining 17 percent almost all Chinese. Muhd. Djinguiz, "L'Islam dans les possessions hollandaises, portugaises et américaines de l'archipel Indien," Revue du monde musulman (henceforth RMM), 7 (January-February 1909), p. 108.

${ }^{30}$ Reid, "Nineteenth Century Pan-Islam," p. 280.

${ }^{31}$ These rulings concerned flying the Riau flag, seating arrangements for princes during an official visit by the Resident, and the number of cannon shots to be fired in greeting the Sultan when he visited Tanjung Pinang.

${ }^{32} \mathrm{~V}$ February 4, 1905, Kab. Litt. A42, Resident de Kanter to Gov. Gen., February 29, 1904, foll. 14-15, and Govt. Sec. to Netherlands consuls at Cairo and Jeddah, November 19,1904 . It is significant that the actual writer of the letter was a haji who previously had been attached to the Sultan of Jambi and was now a teacher in Raja Ali's house. In 1903, the Sultan of Jambi had made another appeal to Turkey, which apparently also reached Sultan Abdul Hamid. Reid, "Nineteenth Century PanIs lam," p. 282.

33V June 15, 1906, 55, Appendix; V February 4, 1905, Kab. Litt. A ${ }^{4}$, Snouck Hurgronje to Gov. Gen., May 7, 1904.

${ }^{34}$ Ibid., and V April 18, 1908, 1, Resident de Kanter to Gov. Gen., January 25, 1905; V June 15, 1906, 55, De Kanter to Gov. Gen., May 18, 1905. 
Raja Ali never actually reached Constantinople, 35 but in any case Abdul Hamid would have been incapable of confronting the Dutch openly. In July 1904, he had made a general appeal to the Dutch queen on behalf of Moslems in the Netherlands Indies, but he was not willing to risk further action. ${ }^{36}$ Apparently unable to arouse any interest in Riau's case, Raja Ali returned home in March 1905, only to find that his halfbrother, the Riau ruler, had succumbed to unrelenting Dutch pressure. Less committed to the Bugis cause than Raja Ali, and possibly unwilling to see the reestablishment of a post which might counter his own position, Sultan Abdul Rahman had at last agreed to conclude a treaty which for the first time would specifically omit any reference to the Yamtuan Muda and which would also give the Governor-General the right to appoint the heir to the Riau throne. ${ }^{37}$

Raja A1i, Raja Hitam, and the leading court members, all with some Bugis blood, refused to be identified with the proposed treaty. Under normal circumstances this would have put a halt to the proceedings, since custom decreed that any contract must be discussed with the court and receive the approval of the senior ministers. The Dutch government nonetheless pressed on. By May, a draft had been drawn up, and in September 1905 the final version was signed by the Sultan alone.38

This unprecedented flouting of adat (custom) put Penyengat in an uproar, but meetings, petitions, and speeches, however heated, were obviously futile. Yet at the same time the Riau court was becoming aware of the opening of another avenue of appeal. The Riau Sultan may have concluded an ignoble treaty which conceded further ground to the colonial administration, but thousands of miles away European prestige had been dealt a formidable blow. On May 27, the Russian fleet had been destroyed by the Japanese at Tsushima, and in early September the Treaty of Portsmouth formalized the Japanese triumph. ${ }^{39}$

The Growth of Japanese Power and

the Spread of Pan-Asian Awareness

Japan's dramatic rise in the late nineteenth century had encouraged burgeoning Asian nationalist movements to believe that an Asian

${ }^{35}$ Some years later it was reported that he had tried to obtain an audience with the Khedive of Egypt. V February 10, 1911, $\mathrm{Y}^{3}$, Note by Resident de Bruyn Kops, December 28, 1910, fo. 11 .

${ }^{36} \mathrm{~V}$ October 6, 1905, 54, Resident de Kanter to Gov. Gen., April 26, 1905; V June $15,1906,55$, Nota van toelichting betreffende Riau en Lingga, February 23, 1906, foll. 13, 20; C. Smit, Bescheiden Betreffende de Buitenlandse Politiek van Nederland, 1848-1919 (The Hague: Nijhoff, 1958), 2, pp. 271-74.

37V October 6, 1905, 54, Resident de Kanter to Gov. Gen., April 26, 1905; V June 15, 1906, 55, De Kanter to Gov. Gen., May 18, 1905.

38V March 21, 1907, 3, Resident de Kanter to Gov. Gen., October 10, 1905. A copy of the final contract is in V June 15, 1906, 55. The Sultan was very anxious for his youngest son to be declared heir to the Riau throne and apparently hoped that the Dutch would prove more amenable to this plan if he signed the contract.

${ }^{39} \mathrm{~J}$ ohn A. White, The Diplomacy of the Russo-Jopanese War (Princeton: Princeton University Press, 1964), pp. 206 ff. 
ally now existed who would stand with them against Western imperialism. Any support they received from the Meiji government, however, was guarded and indirect, and indeed one of the aims of the Meiji oligarchy was to eliminate diplomatic language which spoke "as if the Japanese were on the same level of morality and civilisation as Chinese or other less advanced populations of Asia.. . to whom they bore no real similarity, [inflicting] upon the nation an insult which was not deserved."40 Japan's new leaders were concerned above all with the building of a strong nation state with high international standing. The spread of Japanese political influence in the east Asian region was considered vital, not to liberate Asia, but to protect Japan's own independence, strengthen her economy, and maintain the respect of the world community. ${ }^{41}$

This tendency became apparent initially in relation to Korea, which the Meiji leaders believed should be preserved at all costs from falling under total Chinese control, thereby endangering Japan's security. Peking's despatch of troops to Seoul in June 1894 led almost inevitably to a brief war, in which the Chinese collapsed in the face of overwhelming Japanese military superiority. Despite Japan's victory, however, she suffered the ignominy of being forced by the Western powers to renounce any rights to the Liaotung Peninsula, an act of "international brigandage" 42 which was not easily forgotten. In subsequent years the Japanese flung their national energy into efforts to strengthen their army and navy so that such a humiliation would never recur. By the beginning of the twentieth century this policy was beginning to bear fruit. Established as a "colonizing nation" by the acquisition of Formosa in 1895 and acknowledged as at least a superior Asian state by the abolition of extraterritoriality, Japan found her status in world eyes greatly enhanced by the Anglo-Japanese treaty of 1902 , which provided the prestige of friendship with the worid's greatest power. 43

Though the Meiji government had thus embarked on a foreign policy patterned on that of the West, there was some popular support within Japan for the notion of Pan-Asianism, a united Asia under Japanese aegis. Advocates of this view saw Japan's role in Asia in a variety of ways--as a missionary bringing the benefits of civilization to those less fortunate, as a purveyor of peace and justice, or as the leader of a harmonious union of Asian races. 44 Novels, the forums

${ }^{40}$ Australian National Archives (henceforth ANA) A2219, Vol. I A, Relations of Australia and Japan and Far Eastern and Pacific Questions, 1900-1918, J. Chamberlain to Lord Brassey, October 20, 1897, No. 86.

41Ian Nish, Japanese Foreign Policy, 1869-1942: Kasumigaseki to Miyakezaka (London: Routledge and Kegan Paul, 1977), Chs. 1 and 2; Kenneth B. Pyle, The New Generation in Meiji Japan (Stanford: Stanford University Press, 1969), p. 81; Marlene Mayo, "Attitudes towards Asia and the Beginnings of Japanese Empire," in Grant K. Goodman (ed.), Imperial Japan and Asia (New York: East Asian Institute, Columbia University, 1967), p. 11.

42Yosaburō Takekoshi, Self-Portrayal of Japan (Tokyo: Ritsumeikan University Press, 1939), p. 53; Pyle, The New Generation, p. 180.

${ }^{43 \mathrm{Ni}} \mathrm{sh}$, The Anglo-Japanese Alliance, pp. 226-35.

${ }^{44}$ Mayo, "Attitudes towards Asia," pp. 12-22; Akira Iriye, "The Ideology of Japanese Imperialism: Imperial Japan and China," in Goodman (ed.), Imperial Japan and Asia, p. 35; Jansen, The Japanese and Sun Yat Sen, p. 25. 
provided by patriotic societies, and speeches by politicians, all served as media for the concept of Japan as a guide and model for other Asian countries, encouraging them to cast aside the fetters of feudalism.45

Most supporters of the idea of Japan's leadership in Asia saw their country's future linked principally to east Asia--Siberia, China, Formosa, and Korea. But there were some who looked further afield, to the Nanyō, the Southern Seas. A tiny group, even among the Pan-Asianists, they were nonetheless articulate and prolific. In 1887 , one of their spokesmen, Shiga Shigetaka (1863-1927), published Nanyōjiji (Conditions in the South Seas), in which he deplored the indifference of the Japanese to the onward march of Europeans in the Pacific area. Japan must establish itself as an ally of Asian and Pacific peoples, for "if the coloured races do not now exert themselves, then ultimately the world will become the private possession of the white race."46 Another enthusiast, Suganuma Teifū (1865-89), pressed for more active participation in the region. In a book entitled Shin Nihon no Nanyo no yume (New Japan's Dream of Aspirations to the South Seas), he argued that Japan should protect itself from Western expansion by "helping neighbouring countries, such as Siam, in warding off the western powers' encroachments, or by aiding or achieving control of neighbour ing colonies, such as French Annam, Dutch Java and Sumatra."47

This type of argument, advanced in personal discussions and unofficial meetings, did much to convince certain anticolonial groups in Vietnam and the Philippines that Japan would assist them to end foreign rule. But in Riau during the final years of the nineteenth century there was no counterpart of Vietnam's Phan Dinh Phung or the Filipino Aguinaldo to seize on the hopes held out by Japanese revolutionaries and right-wing patriots, and for the Riau princes any idea of seeking common cause with the Japanese would have been completely alien. In contrast to the time-honored links with Rūm, Japan's impingement on Malay society in the previous two hundred years had been negligible. It was known vaguely as a land of exotic products--silk, porcelain, fans, screens, and costly lacquerware--but its enforced isolation after the Tokugawa proscription of foreign trade in 1636 meant that the Japanese as a people had little concrete identity in Malay eyes.48 While orang Keling (Indians), Chinese, Feringgi (Portuguese), and Siamese appear frequently in Malay texts, the Japanese are conspicuously absent. Even the peripatetic Malay hero, Hang Tuah, has only a chance meeting with orang Jepun, and in this episode they are seen as reckless and unruly swordsmen, infidels who attempt to commit derhaka (treason) against the ruler of Siam.49

45Jansen, The Japanese and Sun Yat Sen, pp. 31, 33, 35, 43; Sanie1, Japan and the Philippines, pp. 73-85.

46Pyle, The New Generation, pp. 55-58, 156-59.

47Sanie1, Japan and the Philippines, p. 87.

${ }^{48}$ M. A. R. Meilink-Roelofsz, Asian Trade and European Influence (The Hague: Nijhoff, 1962), p. 79. After a brawl in Melaka in 1615, the Portuguese also stopped hiring Japanese as mercenaries. I. A. Macgregor, "Notes on the Portuguese in Malaya," JMBRAS, 28, 2 (1956), pp. 23 n. 79, 25.

${ }^{49}$ Ahmad, Hang Tuah, pp. 391-95. This is obviously a reference to the Japanese guard maintained by King Narai (1657-88). 
The years after 1853 saw radical changes in Japanese contacts with foreigners, but in 1871 there was still only one Japanese resident officially registered in Singapore. By 1911, however, the number of Japanese living there had reached 1,409.50 The social backgrounds and occupations of these people, however, were not generally such as to inspire respect. There was a predominance of women, mostly prostitutes, plying their trade in urban centers such as Singapores 1 and in the Chinese mining camps. Some of the males were farmers, but many were small businessmen or wandering peddlers of patent medicines. As a contemporary observer remarked, "There are a few Japanese merchants and commercial men of acknowledged standing [in Singapore], but for the most part the island of the Rising Sun is represented by an undesirable class." 52

Notwithstanding this lack of cultural and historical ties, Japan's new position in world affairs was slowly being impressed on the Riau nobility. In 1883 the enterprising Maharaja Abu Bakar of peninsular Johor, always attuned to changing patterns of diplomacy, made an extensive tour of Japan, where he was granted audiences not only by the members of the Japanese cabinet, the Prime Minister, and the imperial princes, but by the Emperor Meiji himself.53 Though he kept no account of his impressions, there can be little doubt that the stories brought home by his entourage would have created as much interest as the costly gifts which now decorated the Johor palace. Perhaps it was memories of the Maharaja's triumphal tour which prompted the Sultan of Serdang, on the east coast of Sumatra, to make a similar visit in 1898. His request for a royal audience was politely refused, but he was sufficiently impressed with Japanese architecture to hire Japanese gardeners for the landscaping of his palace grounds.54

But of greater significance than the admiration of individual Malay princeswas Japan's new elevated standing among the Europeans. In March 1899, the Tweede Kamer (Lower House) of the Dutch Parliament decided to grant Japanese the same legal status as Europeans and Christians. In the Netherlands Indies reaction was immediate, and both Arabs and Chinese began to press for the same privileges.55 Coming in the wake of Japan's military successes (and, ironically, at the same time as the discussion over the future of the Yamtuan Muda post in

SoYuen Choy Leng, "Expansion of Japanese Interests in Malaya, 1900-1942" (M.A. thesis, University of Malaya, Kuala Lumpur, 1973), pp. 2, 4; Kee Yoh Sieuw, "The Japanese in Malaya before 1942," South Seas Society Jourmal, 20, 1 and 2 (1965), pp. 48-49.

51Bore1, Wijsheid en Schoonheid, pp. 51-53; Kee, "The Japanese in Malaya,"p. 67.

$52 \mathrm{Kee}$, "The Japanese in Malaya," pp. 48-49; A. Wright and H. A. Cartwright (eds.), Twentieth Century Impressions of British Malaya (London: Lloyd's Greater Britain Publishing Company, 1908), p. 127.

${ }^{53}$ Datuk Abdullah bin Mohammed, "The Travels of Abu Bakar, Maharaja Johore, to the Far East," Malaysia in History, 14, 2 (1971), pp. 3-9.

$54 \mathrm{~V}$ August $21,1921,21$, Resident Ballot of Medan to Gov. Gen., November 29, 1906; Dutch envoy in Tokyo to Gov. Gen., March 14, 1907.

55De Locomotief, March 4, 1899, p. 1; Reid, "Nineteenth Century Pan-Islam," pp. 280-81; J. S. Furnivall, Netherlands India: A.Study of Plural Economy (Cambridge: Cambridge University Press, 1939, 1967), p. 241. 
Riau), the Dutch announcement made a telling impact. It was a public and unambiguous acknowledgment that a nonwhite, non-Christian race could actually be regarded as the equal of the West and classed as "civilized," the universal catchword of the late nineteenth century.

As the twentieth century began, then, if ideas about Japan in Riau were still inchoate, the name nonetheless conjured up the image of a country which had successfully answered the Western challenge. Even Britain had cultivated Japanese friendship, and in the eyes of the Riau court Japan soon appeared to be advancing to the first rank in the world community, its prestige rivaling, if not surpassing, that of the Netherlands. In April 1903, as Dutch officials expressed concern that their representatives at the Osaka Exhibition had received lower honors than those accorded Canada and Austria, 56 the Acting Resident of Riau was complaining that the Sultan and nobles considered the Dutch government weak, "while the recent visit of the Japanese training squadron fleet to Batavia was seen as the beginning of the annexation of the Netherlands Indies by Japan."157

The growing belief in Riau that Japan was strong enough to oust the Dutch from their entrenched position in the archipelago was confirmed by momentous international events. In February 1904, the same month that the Riau court had decided to appeal to the Raja Rūm, Japan declared war on Turkey's old enemy, Russia, and this war caught the imagination of the entire world. All over Western Europe, music hall songs and illustrated magazines dwelt on the plucky exploits of Japanese soldiers against the antics of the lumbering Russian bear.58 Initially, the Dutch had had no doubt that the Japanese would be defeated, and in Singapore Japan's ally, Britain, mobilized troops and readied defenses.59 But as the tide of battle turned in Japan's favor, Europeans in Southeast Asia and the Pacific region began to contemplate the implications of a Japanese advance into the area. In October 1904, the Riau Resident received an agitated telegram from Batavia, informing him that a warship had been sent to patrol the Riau archipelago because of fears that the Japanese might occupy a remote island in order to attack the Russian fleet as it sailed north.60 Such apprehension among colonial administrators could but be noted by the people they governed. In Singapore, the Japanese community greeted their countrymen's every victory with celebrations in the streets, while European and local newspapers carried detailed reports on the hostilities. ${ }^{61}$ Malays who

56V March 3, 1905, C $C^{6}$, Dutch Envoy in Tokyo to Gov. Gen., November 12, 1904.

57V August 27, 1904, 8, Resident de Breedveldt Boer of Tanjung Pinang to Gov.

Gen., April 27, 1903, No. 50 (Geheim). See also below, n. 115 .

${ }^{50}$ Nish, The Story of Japan (London: Faber, 1968), p. 120.

1904, p. 3.

${ }^{59}$ See, for example, De Locomotief, January 11, 1904, p. 2, and February 13,

60V November $30,1904, Q^{25}$, Govt. Sec. to Resident de Kanter, October 14, 1904 .

61De Locomotief, February 12, 1904, p. 3. This paper printed a map every day with troop positions marked and a description of the latest events; Retrodhoemilah, a major Indonesian-language journal, devoted almost half of its space in 1905 to details of the campaigns. Nagazumi, "An Indonesian's View," p. 76. 
were illiterate could still see the colored illustrations of Japanese conquests for sale in the market places62 and listen enthralled as the significance of these was explained. In the words of the Riau Resident, news of the war "was on everyone's lips."63

As the inevitability of a Japanese victory became obvious, speculation grew. Where would the conqueror turn next? No doubt stimulated by the anxiety of the colonial government, rumors circulated that, having defeated Russia, the Japanese would devote their attention to the Netherlands Indies.64 In Sumatra, a missionary remarked that many Moslems "set all manner of hopes upon the Russo-Japanese war, and the speedy eviction of the Dutch . . . was the topic of eager conversation."65 A Cairo newspaper, the $L i w \bar{a}$, published an article attributed to "our correspondent in Java" in which Japan was compared to a cat which would leap at the throat of its European tormentors. The Dutch, claimed the writer, would be in no position to resist a Japanese attack.66 For a time a rumor circulated that a Japanese fleet had actually been sighted off Singapore and that Batavia had brought in more warships to strengthen the Indies' defenses.67

While Raja Ali was in Cairo during his mission to the Middle East, he probably heard of the purported Japanese attack on the Netherlands Indies recounted in papers such as the $L i w \vec{a}, 68$ but even before he returned home some members of the Riau court decided to seize the opportunity of winning a new and powerful al1y. In March 1905, the chief of an outlying island in the archipelago came to Singapore to request a meeting with the Japanese consul. According to accounts received in Batavia, his aim was to solicit Japanese help in having the position of Yamtuan Muda restored and in preventing the proposed treaty with the Dutch from being finalized.69 Though this envoy was unable to obtain the desired audience, the Riau princes were not discouraged, and the news of Russia's defeat served to intensify their efforts. In June 1905, shortly after the draft contract with the Sultan had been drawn up and only two weeks after the Battle of Tsushima, Raja Hitam went to Singapore on the pretext of setting up a medicine shop in cooperation with a Japanese firm. He did not return until August, and in September the Batavian government received an anonymous letter claiming that Raja Hitam's real reason for visiting Singapore had been to negotiate the "handing over of the Kingdom of Lingga and Riau to Japan in

${ }^{62}$ Thijs, De InvZoed, p. 18; Ali Sastroamidjojo, Tonggak-Tonggak di Perjalananku (Jakarta: Kinta, 1974), p. 10.

146.

63V March 21, 1907, 3, Resident de Kanter to Gov. Gen., October 10, 1905, No.

${ }^{64} \mathrm{~V}$ October 12, 1908, $\mathrm{T}^{19}, \mathrm{G}$. Ghouse, envoy of Sultan of Aceh, to British Sec. of State, May 8, 1907, fo. 4 .

${ }^{65}$ Simon, Progress and Arrest, p. 39.

66V January 12, 1905, $W^{1}$, Snouck Hurgronje to Gov. Gen., November 12, 1904.

67Nagazumi, "An Indonesian's View," p. 77.

${ }^{68}$ The Liwā, article appeared on September 4, 1904; Raja Ali Kelana and his party arrived in Cairo on October 27. V April 18, 1908, Dutch Agent in Cairo to Govt. Sec., December 18, 1904.

${ }^{69} \mathrm{~V}$ March 21, 1907, 3, Resident de Kanter to Gov. Gen., October 10, 1905. 
the Sultan's name."70 The source of this information was admittedly unknown, and its veracity therefore open to doubt, but the Riau Resident had also been reliably informed of proposals among the Riau nobles to call on the Japanese for assistance. 71

To see this development as merely a desperate move by a beleaguered elite is, I would suggest, to underestimate the degree to which the Riau court had responded to the notion that they could seek affinity with Japan on the sole basis of being orang timur. It would have been unthinkable for Raja Hitam's father, Raja Ali Haji, that Riau, however hard pressed, could ever have gained anything from Japan. His vision and his hopes, like those of his generation, had been fixed on the Middle East, and above all on the Raja Rūm. Now a large number of the Penyengat princes were willing to place their future in Japan's hands. How, one might ask, was this faith inspired? Other Indonesians had expressed admiration for Japan, but they had recognized the realpolitik which would certainly govern Japanese foreign policy in Asia; still others were too anti-Chinese to accept the idea of Asian solidarity, even under Japanese leadership. 72

From the standpoint of the Riau nobles, what imparted credibility and authority to the new image of Japan was the fact that the most influential men in the Islamic world, who had for so many years laid down the standards by which Riau's religious, social, and political life was governed, were themselves directing the attention of their Moslem brethren to the Japanese achievement. In the Middle East, Japan's entry into the modern world and its victory over Russia were unanimously acclaimed across the spectrum of orthodox Islam.

\section{Moslem Press Responses to Japan's Rise}

Those "moderates" who were convinced that Moslems had to learn from the West if Islamic society was to survive felt that their arguments had been vindicated. The secret of Japan's success was her ability to master Western technology and science, while at the same time avoiding the adoption of European customs and morals. Japan had demonstrated that a non-Western, Asian civilization had inherent strength; Moslems could only benefit from closer association with Japan, especially in educational matters. Only through knowledge could the Islamic community attain equality with the West. In the euphoria which followed the conclusion of the war, eager young Moslems from a number of countries left to study in Japan. ${ }^{73}$

70 Ibid. Raja Hitam was consequently forbidden to return to Singapore.

71 Ibid.

${ }^{72}$ Nagazumi, "An Indonesian's View," p. 79; Taufik Abdullah, "Modernization in the Minangkabau World: West Sumatra in the Early Decades of the Twentieth Century," in Claire Holt (ed.), Culture and Politics in Indonesia (Ithaca: Cornell University Press, 1972), p. 216.

${ }^{73}$ F. Farjene1, "Le Japon et l'Islam," RMM, 1 (November 1906), pp. 101-2; Lewis, The Emergence, p. 326; Niyazi Berkes, The Development of Secularism in Turkey (Montreal: McGill University Press, 1964), p. 359. 
On the other hand, the triumph of Japan also made its appeal to those Moslems who yearned for Islam to play a more militant role in world affairs. For them, the Japanese victory in 1905 was not only a victory of Asians over non-Asians; it also meant the defeat of a kafir people which during the last century had battered down the doors of the ottoman Empire. In 1890, Sultan Abdul Hamid had already made a gesture of friendship to Japan by sending one of his warships there with a medal for the Emperor, an event which had created widespread excitement in Singapore. Now a Turkish-Japanese alliance was openly advocated in the Middle Eastern press. ${ }^{74}$ It was known that Japan was also among the countries included in Abdul Hamid's proselytizing campaign,75 and supporters of Pan-Islam were emboldened to predict great things in store. Somewhere--possibly India--the rumor arose that Japan was considering conversion to Islam.76 However fantastic in retrospect, this rumor was at the time eagerly passed along and seriously discussed. As far afield as Sumatra it was reported that "Moslems in India . . had addressed a petition to the Emperor of Japan that he would place himself at the head of Moslems and drive all the Christians out of Eastern Asia."77 One of the most widely read Cairo journals, the Mu'ayyad, whose Singapore contributors included one of Raja Ali's associates, $\mathbf{7 8}$ pointed out the implications a Moslem Japan would have for the political situation in the Middle East now that Turkey was confronted by an alliance of Russia, England, and France.79 The departure of Egyptian, Indian, Persian, and Turkish missionaries to Japan, reported in the $M u^{\prime}$ 'ayyad and other papers, was accompanied by widespread

${ }^{74}$ Anthony Reid, The Contest for North Sumatra, 1858-1898 (Kuala Lumpur: Oxford University Press, 1969), p. 258; "Revue de la presse musulmane," RMM, 25 (December $1913)$, p. 384. In 1907 it was rumored in Pontianak that the Sultan of Turkey, with the aid of the Japanese, would drive the Europeans out and restore Pasir to the Sultan of Pontianak. V May 29, 1908, 43, Mailrapport 1642, Kort Verslag, October 1907.

${ }^{75}$ Lewis, The Emergence, p. 342.

${ }^{76}$ Farjene1, "Le Japon et 1'Islam," p. 103. Fernand Farjene1, a member of the Asiatic Society of Paris and Dean of the Collège Libre des Sciences Sociales, was a Sinologist who had developed a particular interest in Chinese Moslems.

77Simon, The Progress and Arrest, p. 39. Some helpful comments about the acceptance of seemingly wild rumor can be found in Tamotsu Shibutani, Improvised News: A Sociological Study of Rumor (Indianapolis: Bobbs-Merri11, 1966). He stresses in particular the relaxation of norms governing the acceptance of information when the situation is one of extreme frustration or excitement. Only people who "do not share the perspective of the participants" are amazed at the currency of wild or bizarre rumors; see pp. 17, 12, 39, 77; also P. A. Lienhardt, "The Interpretation of Rumor," in J. H. M. Beattie and R. G. Lienhardt, Studies in Social Anthropology: Essays in Memory of E. E. Evans-Pritchard by His Former Oxford ColZeagues (Oxford: Clarendon Press, 1975), pp. 105-31.

78Farjene1, "Le Japon et 1'Islam," p. 105; "La presse musulmane," RMM, 9 (December 1909), p. 674; "Faits divers," RMM, 1 (December 1906), pp. 277-78; L. Bouvat, "La presse musulmane," RMM, 1 (November 1906), pp. 122-29. Syed Mohd. bin CAgil of Singapore, who was involved in founding the Malay journal al-Imam, was also a contributor to al-Mi'ayyad. Usuf A. Talib, review of Bibliography of Malay and Arabic Periodicals in the Straits Settlements and Peninsula Malay States, by W. R. Roff, in Journal of Southeast Asian Studies, 5, 2 (1974), p. 280; L. Bouvat, "La presse musulmane," RMM, 9 (October 1909), pp. 328-29.

${ }^{79}$ Farjenel, "Le Japon et l'Islam," p. 105. 
publicity given to a Congress of Religions to be held in Tokyo in 1906. According to press releases, this conference, over which the Mikado himself would preside, had been entrusted with the task of determining the most suitable religion for Japan.80 Alleged eyewitness tales of Japanese responses to Islamic teaching contributed to notions of spectacular advances by the True Faith. About 1909, for example, the editor of the Egyptian paper al-Irshad made a trip to Japan and his account of his experiences, called simply Trip to Japan (al-Rihlat alYabaniyya), gave the impression that mass conversions were taking place across the country. 81

The large Indonesian community living in Mecca and other Middle Eastern cities must have responded enthusiastically to the accounts of Japan's great knowledge, its mighty industries, its success in battle, and particularly its interest in the Moslem religion. Riau was not alone in its readiness to seek support and assistance from the Japanese. 82 But at the same time the steady stream of news about Japan brought back to Riau by returning pilgrims ${ }^{83}$ was reinforced closer to home by the establishment in Singapore of a new Malay journal, al-Imam (The Leader).

Al-Imam, modeled on the Egyptian paper al-Manār (The Lighthouse), and reflecting the reformist views of al-Azhar University, first appeared in July 1906 and was widely distributed throughout the Peninsula, Sumatra, and Java. The fidelity with which it relayed Arabic opinion on a variety of issues assured it a high standing in the Riau court, where it was read by the Sultan himself.84 The interest of the

${ }^{80}$ Ibid., pp. 103, 105-12.

81"Autour du monde musulman," RMM, 8 (June 1909), p. 283. Another view popular in the Middle East at this time was the argument that Japan had progressed because Buddhism had absorbed the soul of Islam. Berkes, The Development of Secularism in Turkey, pp. 342, 361 .

${ }^{82}$ The rulers of Aceh, Deli, and Serdang were reported to be seeking Japanese support, and it was rumored that the Japanese had smuggled gunpowder and weapons into Serdang and Batu Bahara. Four princes from Goa in Sulawesi arrived in Singapore in September 1906 en route to study in Japan, and three months later two prominent nobles from the court of Kota Waringin in Borneo also embarked at Singapore for Japan. In December a Japanese newspaper, the Kokumin, published a report of their visit to Tokyo. Dutch authorities believed that these nobles had hoped to recruit Japanese help in their efforts to gain control in Kota Waringin; well after their return rumors persisted of Japanese intervention in Borneo. V August 21, 1921, Resident Ba1lot of Medan to Gov. Gen., November 29, 1906; V October 12, 1908, $\mathrm{T}^{19}$, Petition by SuItan Alauddin Mohd. Daud of Aceh to Emperor of Japan, September 20, 1905; V June 9, 1908, Dutch Consul in Singapore to Gov. Gen., October 12, 1905, October 26, 1906, November 7, 1907; V May 29, 1908, Extract from Kokumin Shimbun; V May 13, 1909, 43, Controleur of Samput to Resident of South and East Borneo, April 18, 1907, and Resident of South and East Borneo to Gov. Gen., October 13, 1908.

${ }^{83}$ The numbers of pilgrims from Riau in the late nineteenth and early twentieth centuries is given in J. Vredenbregt, "The Haddj: Some of Its Features and Functions in Southeast Asia," BKI, 118, 1 (1962), pp. 140-41. From 1897 to 1914, 939 people are registered as having made the haj, and by 1926 Riau had about 111 pilgrims per 100,000 inhabitants, the sixth largest percentage in Indonesia. Ibid., p. 152 .

${ }^{84}$ Hamka, Ajahku. Riwajat Hidup Dr. H. Abd. Karim Ammullah dan Perdjuangan Kaum 
Penyengat princes in al-Imam was also stimulated because some of their number, notably Raja Hitam and Raja Ali, were active contributors, while the editors were personally known to them. The founder, shaykh Mohd. Tahir Jalauddin, had been educated at al-Azhar and now spent. much of his time traveling in Riau-Lingga and the Peninsula giving religious instruction. He shared Raja Ali's interest in education, and in 1908 the two cooperated to set up a school in Singapore, al-Iqbal al-Islamiyyah, under al-Imam's auspices and with funds provided by Raja Ali.85 Another editor, Sayyid Shaykh bin Ahmad al-Hadi, had been adopted by Raja Ali Haji, Raja Hitam's father, and raised on Penyengat, where he later married a Riau woman. For a time Sayyid Shaykh was in charge of Riau's rumah wakaf, the hostel for religious travelers, and he was a prominent member of the Rushdiyyah Club. He and Raja Hitam were particularly fond of debating and would often sit far into the night discussing Islamic theology and the reasons for the general backwardness of Moslems. Sayyid Shaykh had spent several years studying in the Middle East and still subscribed to a number of Middle Eastern periodicals. He also acted as business agent for Raja Ali Kelana, and accompanied the latter on his abortive mission to Turkey in 1904. Although Sayyid Shaykh had taken up residence in Singapore, he and Raja Ali, whom he called "my father and teacher," remained intimates.86

The relationship between the founders of al-Imam and the Riau court meant that, as Snouck Hurgronje remarked, the journal was "a suitable place for [Raja Ali and his advisers] to publish their desires and grievances."87 An editorial published in September 1906 pondered the fate of those countries which had lost their independence and of which nothing remained except "a collection of texts and stories."s A number of articles in al-Imam clearly reflected the resentment felt on Riau towards the changes in court protocol introduced by the colonial government and above all the abolition of the Yamtuan Muda post. Tengku Osman, the Sultan's eldest son and Raja Ali's son-in-law and protégé, who had been at school in Cairo during the crisis over the 1905 treaty, returned in April 1906. He was appalled at what his father had done. In its November issue, al-Imam published verbatim a speech he made to the Rushdiyyah Club. "I think, sirs," he had said, "you must all be very worried and sad to see what has recently occurred in our beloved homeland."Bg Another article by Sayyid Shaykh inveighed

Agama di Sumatera (Jakarta: Penerbit Widjaya, 1958), p. 77; V April 18, 1908, 1, Resident de Kanter to Gov. Gen., January 24, 1907. For a description of this journal, see Roff, The Rise of Malay Nationalism, pp. 65-66; "Revue de la presse musulmane," RMM, 2 (May 1907), p. 404.

${ }^{85}$ Roff, The Rise of Malay Nationalism, p. 79; Noer, The Modemist Moslem Movement, p. 34. Because of his love for al-Azhar, the Shaykh added "al-Azhari" to his name. Al-Imam, 1, 5 (November 17, 1906), pp. 160-61.

86Roff, The Rise of Malay Nationalism, pp. 56-59, 62; V April 18, 1908, Resident de Kanter to Gov. Gen., January 24, 1907, fo. 3; S. H. Tan, "The Life and Times of Sayyid Shaykh al-Hadi" (B.A. Hons. thesis, University of Singapore, Dept. of History, 1961), pp. 1-5.

87V June 19, 1907, $\mathrm{N}^{12}$, Snouck Hurgronje to Min. of Colonies, June 13, 1907.

${ }^{88}$ Al-Imom, 1, 3 (September 19, 1906), p. 77.

${ }^{89} \mathrm{AZ}$-Imom, 1, 5 (November 17, 1906), p. 138. A1though tanah air does appear in al-Imam, the word most commonly used for homeland is the Arabic wațan, the original 
against the foreigners for placing the Eastern peoples under slavery, for their duplicity and disrespect to Eastern rulers, and for closing the doors to knowledge ( $\left.i I_{m u}\right) .90$

Malay problems (and, by inference, those of Riau), Sayyid Shaykh went on, could only be overcome by the active fostering of ilmu. This had, indeed, been the traditional prescription for the ills of Islamic society, but it is clear that to Sayyid Shaykh the connotations of ilmu were very different from what they had been for the previous generation. To Raja Ali Haji, Raja Hitam's father, ilmu was essentially knowledge of religion gained through studying with learned teachers, reading edifying books, and adhering to tradition.91 For his sons and their contemporaries, on the other hand, the conception of ilmu had expanded to include knowledge of modern technology and the sciences. They believed that such knowledge had become a Western prerogative only because the Western colonial powers had prevented its dissemination among Asians by denying them education. Colonizing governments knew that the possession of ilmu was a powerful weapon which would enable a country to exploit its potential and to attain civilization (tamaddun). Though the meaning of tamaddun was never fully defined, al-Imam's readers were made aware that it constituted the current criterion for judging a country's international standing. Those nations which were "civilized" were members of a select group, bangsa yang berizmu (countries possessing knowledge), to whom were unfolded all the secrets of the technological age, "the amazing things which have appeared in the world."92 Japan, it was clear, had been admitted into this privileged circle, and the key to the civilization which Japan had attained was ilmu. It was through ilmu that a small country like Holland could extend its rule over millions of people, "and the Japanese, fewer than fifty million, could never have defeated their enemies who were hundreds of millions strong, if they were not in possession of that know1edge."193 Even Europeans, acknowledging Japan's tamaddun, went there to study.94 It had seemed, one contributor wrote, that Asia's greatness had passed, but now a powerful Eastern people had emerged which would bring light to those who lived in darkness, raise high those who had been low, and bring life to those who had been dead.95

In 1907, al-Imam's editors accordingly sponsored the translation and distribution of an Arabic work on Japan, al-Shams al-Mushriqa (The

meaning of which was origin or habitation. By the middle of the nineteenth century watan was commonly used in the Middle East to mean country or homeland. Lewis, The Middle East and the West, p. 76.

${ }^{90} \mathrm{AZ}$-Imam, 1, 6 (December 18, 1906), pp. 170-72.

91 See Andaya and Matheson, "Islamic Thought and Malay Tradition," for a discussion of this point.

92AZ-Imam, 1, 6 (December 18, 1906), pp. 170-73 and 190. See also below, n. 102 .

93AZ-Imam, 1, 10 (Apri1 14, 1907), p. 314; Tan, "The Life and Times of Sayyid Shaykh," pp. 30-31. Japan's possession of knowledge had previously been stressed in other Indonesian journals. See, for example, Nagazumi, "An Indonesian's View of Japan," pp. 75-76, and Taufik Abdullah, "Modernization in the Minangkabau World," p. 220.

$$
\begin{aligned}
& \text { 94AZ-Imam, 1, } 6 \text { (December 18, 1906), pp. 190-91. } \\
& { }_{95}^{9} \text { Ibid., and 1, } 2 \text { (August 21, 1906), p. } 57 \text {. }
\end{aligned}
$$


Rising Sun) by the Egyptian nationalist Mustafā Kāmil. Subscribers were informed that the book, entitled Matahari Memancar in Malay, was valuable not only as a history of Japan, but also as a demonstration of how the country had attained civilization through the industriousness of its people.96 In an article submitted some months later, Sayyid Shaykh bin Ahmad carried these arguments further, castigating Malays for their submission to colonial rule.

We believed completely that we people of the east [orang sebelah timur] were lacking in ability. Not for us was perfect akal [intelligence], or strength of vision. We held fast to beliefs of this kind until we heard about the Japanese, an Asian race adorned with ilmu that supported a crown of victory and fame. They worked to increase the natural riches which were once again found in Asia.

Malays had failed to achieve the same progress, Sayyid Shaykh continued, because they had forgotten the commands of their religion to spread education and knowledge; they had not been prepared to learn from the Europeans and had been too indolent to follow the example of the Japanese.97

For the editors of al-Imam, Japan's status as an international power and an ally of Britain did not lessen its standing as an Asian nation. In their view, it was clearly aligned with the "black races" against the white.98 The military might of Japan was unquestioned, for "all the world knew" that it had just defeated Russia and, should war break out between Japan and the United States, the former, with its great sea power, would undoubtedly be the victor.99 By the same token, Japan could easily defeat the Netherlands Indies. If the colonial government persisted in its harsh exploitation, the people of the Indies would rise up, free themselves from colonial tyranny, and place themselves under Japanese rule, which would be "like going from hell to heaven."100

Nor did az-Imam ignore the question of Japan's touted conversion to Islam, which had been so keenly discussed in the Middle Eastern

96AZ-Imarm, 1, 11 (May 14, 1907), p. 354; 1, 12 (June 12, 1907), pp. 263, 285. See also Roff, The Rise of Malay Nationalism, p. 134 n. 23; Lewis, The Middle East and the West, p. 55. Datuk Abdullah bin Mohammed informs me that the translation, by Abdullah bin Abdul Rahman (1ater Datuk and Head of the Department of Religion, Johor), was widely read by Malays until just before World War II, when it became scarce, although it was never actually banned. Personal communication, May 25, 1976. It is interesting to note, in contrast, the low standing of Turkey and Egypt in Japan during this period. See Pyle, The New Generation, pp. 115, 167.

97AZ-Imam, 2, 1 (July 12, 1907), pp. 25-26.

${ }^{98} \mathrm{Al}$-Imam, 1, 8 (February 14, 1907), p. 253; and 1, 2' (August 21, 1906), p. 62 . The writer of the latter article contended that England was simply using Japan as a means of possible support should it be faced with a revolt in India and that now it was even showing signs of friendship with Japan's enemy, Russia. For a discussion of the political ideas in $a l$-Imam, see Abdul Aziz bin Mat Ton, "Gerakan Ansarul Sunnah dalam Kegiatan Kaum Muda Melaka" (Long Essay written for History Department, University of Malaya, 1972), pp. 17-33. 253-58.

${ }^{99}$ See al-Imam, I, 2 (August 21, 1907), p. 60; and 1, 8 (February 14, 1907), pp. ${ }^{100} \mathrm{Al}$-Imam, 1,7 (January 5, 1908), pp. 224-26. 
press. In the first issue, under the heading "Turkey and Japan," the editors described the proposed Congress of Religions to be held in Tokyo, reporting that the Sultan of Turkey had already sent three representatives and had exchanged telegrams with the Emperor himself.101 The progress of Islam in Japan was followed closely; the same issue contained an analysis of the advantages which would accrue to Japan should it embrace Islam. The ruler of Ethiopia had adopted Christianity, the argument ran, but had he been accepted as an equal by the West? Had he been helped on the road to civilization? The Moslem community, on the other hand, would welcome Japan as a member and treat it as a brother. Japan would certainly then become the most powerfu1 nation on earth, allied with millions of Moslems throughout the world and honored by all other countries.102 But, as another article pointed out some months later, it was not only Japan which would benefit. If the Japanese adopted Islam as their state religion, fellow Moslems could hope for both military assistance and intellectual enlightenment.

We would be able to mingle with them like water with sugar [seperti air dengan gula] and we could study from them and be taught by them about all the amazing things which have recently appeared in the world. . . We would then enter into the group of those people who are civilized . . . and the benefits would pass to our descendants. 103

Although the same writer realistically acknowledged that conversion was unlikely among a people who had "worshipped idols" (menyembah berhala) for so long, their apparent lack of any true religion did not detract from their possession of all the secrets of ilmu. Japan had never been colonized, because it had mastered these secrets; if the other countries of Asia failed to follow this example, they would ultimately be totally dominated by the bangsa yang berilmu.104

One of the publicized aims of al-Imam was "to wake Moslems from their sleep... and to communicate news of hope to them."105 No matter that most of its articles were translations of pieces which had already appeared in al-Manar or other Middle Eastern journals. If anything, this fact gave its message even greater authority. Throughout the two years of its existence, the journal reiterated in Malay the lesson that Asians, and specifically Moslems, could help themselves on the path to progress and civilization: the achievement of Japan stood as proof. But the argument did not stop there. As an Asian country, Japan would willingly share its great knowledge with its less fortunate fellows and in so doing would stand forth as Asia's leader and liberator. Japan held out the hope that the iniquity of colonial rule would soon come to an end.

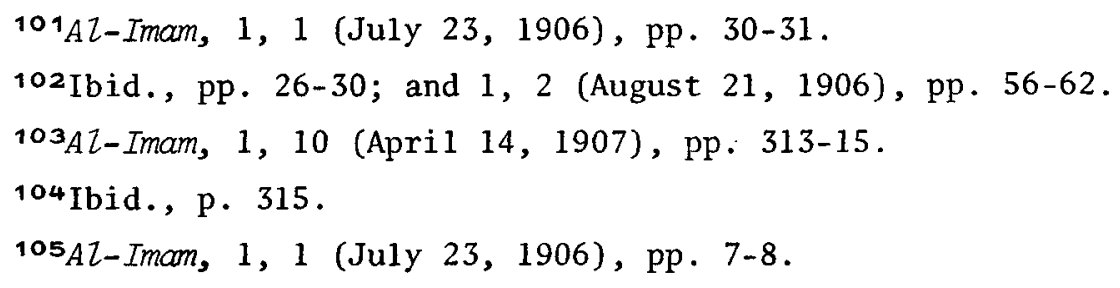


The Dutch colonial government, already concerned at the popularity of the slogan "Asia for the Asians," regarded Japan's rising status in the Indies with apprehension. Responding to inquiries from Batavia, a number of Residents from different areas described the prestige accorded even the lowliest Japanese peddler. In Riau, officials remarked that the medicine-sellers who made their way between the scattered islands of the archipelago were granted considerable respect, given free passage on Malay perahu, entertained by local chiefs, and of course addressed as tuan (sir) as befitted their European rank.106 Pressed for stories, they narrated tales of Japanese power and the feats of the Russo-Japanese war, and one can imagine that these accounts assumed the same place in evening gatherings as had the recitation of traditional hikayat. 107 Rumors had also arisen that the ubiquitous medicine-sellers were in fact spies sent to reconnoitre the Indies prior to an eventual attack, 108 and the Dutch watched their growing numbers nervous1y. In its issue of May 14, 1908, the Semarang newspaper De Locomotief expressed the general fear of a war between Japan and the United States, and of Japan's domination of the entire Pacific area should it capture Hawaii and the Philippines.109 Beginning in 1907, the Governor-General required that 1 ists be made of the permits issued to Japanese intending to travel in the Indies, and investigations were ordered into any development which suggested a further increase in Japanese influence, such as the founding of Japanesetype schools by Chinese.110

In the Riau area the economic presence of the Japanese now represented a far greater threat to Dutch interests than the little store

${ }^{106 \mathrm{~V}}$ March 28, 1914, $\mathrm{F}^{6}$, Controleur of Tanjung Pinang to Resident of Riau, November 5, 1913 (describing the situation prior to 1911), and Civiele Gezaghebber of Tanjung Belitung (Pulau Tujuh) to Resident of Riau, November 28, 1913.

107 Stories of Japan's greatness were widespread throughout the area. A Malay prince from Kota Waringin in Borneo, for instance, told a reporter from the Hochi Shimbun in Tokyo that in his homeland Admiral Töjö was considered a god, "mightier than a poisoned arrow." V May 29, 1908, 32, Appendix 2, Extract from Hochi Shimbun, January 4, 1907.

${ }^{108} \mathrm{~V}$ March 28, 1914, $\mathrm{F}^{6}$, Resident of Ceribon to Gov. Gen., November 28, 1913. In Malaya the British government was opposed to allowing those Japanese doctors who were not university graduates to practice. Japan finally forced the issue in 1916, but it is interesting to note that in 1907 the Sultan of Trengganu hired a Japanese medical attendant, Kondo, who later entrenched himself in the ruling elite and was primarily responsible for bringing other Japanese to Trengganu to develop mining concessions after 1910. Personal communication from Leslie Robert (Monash University), July 22, 1976; Yuen, "Expansion of Japanese Interests," p. 114.

${ }^{109}$ De Locomotief, May 14, 1908, p. 1. See also Surabaya HandeZsblad, October 12 , 1909, p. 2, which warns the government to be wary of Japanese travelers sketching railways and the like in the Indies.

$110 \mathrm{~V}$ January 8, 1908. Circular by Govt. Sec., December 3, 1907; V January 4, 1908, Dutch envoy in Tokyo to Gov. Gen., October 22, 1907; V March 5, 1908, Y ${ }^{5}$, Director of Education to Gov. Gen., January 27, 1908; Resident of Surabaya to Director of Education, January 10,1908. This fear, of course, became much more pronounced after the outbreak of the First World War. See "Japan een Gevaar voor Onze Oost?" De Indische Gids, 38, 2 (1916), p. 182. 
stocked with Japanese goods which Raja Hitam had set up in 1905.111 Following the rubber boom of 1909 , a number of Japanese had begun to investigate the possibility of investing in rubber plantations in Singapore and neighboring Johor. From a total area of 92 acres in 1907, Japanese-owned estates increased to 83,750 acres by 1911 , and in the following year a Japanese Planters' Association was established in Singapore.112 From this base Japanese business concerns expanded further. They became involved in the lucrative copra trade and made efforts to purchase coconut plantations in outlying areas of the Riau residency. Despite Dutch insistence on the illegality of such transactions, Raja Ali and the Sultan of Riau secretly negotiated the sale or rental of certain islands as well as mining and copra concessions to individual Japanese. By 1914 the Riau Resident admitted that it was simply not possible to eliminate either the Japanese or their capital from the archipelago.113

The military power of Japan also became increasingly obvious. After the Russo-Japanese war, Japan, as Britain's ally, was able to expand its naval patrols as far south as Singapore,114 and cruising Japanese fleets appeared more and more frequently in the Pacific area. In October 1910, the Sultan of Riau told the Resident that he had received a visit from three Japanese, led by a former army officer who had served under General Ōyama during Japan's war against Russia. According to the Sultan, the group had been sent by the Japanese government "just to look around."115 Though the identity of these officers remains a mystery, they were clearly anxious to impress the Sultan with accounts of Japanese involvement in the Indonesian archipelago. The ruler of Kota Waringin, they said, was attending school in Tokyo, 116 and during the next year the Japanese government planned to issue a dictionary in Japanese, English, and Malay. Lessons in Malay were a1ready being given in Tokyo at the School for Foreign Languages by

111V March 21, 1907, 3, Resident de Kanter to Gov. Gen., October 10, 1905.

112 Yuen, "Expansion of Japanese Interests," p. 25; Kee, "The Japanese in Malaya," p. 53.

${ }^{113 \mathrm{~V}}$ September 15, 1913, 52, Resident de Bruyn Kops to Gov. Gen., June 28, 1913; V February 25, 1914, $\mathrm{C}^{4}$, De Bruyn Kops to Gov. Gen., December 1, 1913, and Dutch Consul in Singapore to Gov. Gen., November 20, 1913; V July 9, 1914, 45, Resident Veenhuyzen to Gov. Gen., May 10, 1914; Mailrapport 1405, 1914, "Memorie van Overgave" by Resident de Bruyn Kops, March 3, 1914.

114 Yuen, "Expansion of Japanese Interests," p. 122.

$115 \mathrm{~V}$ February 20,1911, $\mathrm{L}^{4}$, Resident de Bruyn Kops to Gov. Gen., October 14 , 1910. Since the late nineteenth century, Japanese vessels has cruised the Pacific area as part of a training program for naval cadets. These fleets often carried special observers on board, a fact which Western powers apparently only began to notice during World War I. In 1891, for instance, Miyake Setsurei, a university lecturer noted for his enthusiastic support for Japanese expansion in the Nanyō, was allowed to accompany a naval training mission in the southern Pacific. Pyle, The New Generation, p. 159; Saniel, Japan and the Philippines, p. 171; V February 25, 1914, $\mathrm{C}^{4}$, Adviser for Japanese and Chinese Affairs to Gov. Gen., August 26, 1913; ANA A2219, II (Conf. No. 188, 36389, B-N), Conyngham Green to Sir Edward Grey, July 8, 1913.

116 Some nobles from Kota Waringin had gone to Tokyo in 1909, which may have lent some credibility to this report. See above, n. 82. 
Straits Settlements Malays who, according to the Sultan, were paid high salaries. ${ }^{117}$

The impression of Japanese fascination with the Malay world conveyed by the Sultan of Riau's guests was not wholly without basis, for the area was attracting greater attention within Japan itself. One authority has seen 1910 as the point at which Japan became a "Pacific" power, 118 but increasing interest in the Indonesian archipelago can be detected well before this. In 1907, for instance, a chair in Malay was established at Tokyo University, and the following year sixteen diplomas were awarded.119 An invitation was also issued to young Indonesians, encouraging them to complete their education at this prestigious institution; and, as the sultan had been informed, from 1908 on, Malay had been included in the syllabus of the Tōkyō Gaikokugo Gakkō (School for Foreign Languages). 120 At the same time journalists, PanAsianists, minor politicians, and nationalists who had long pressed for more Japanese involvement in the affairs of the Southern Seas, intensified their efforts to influence government policy. One of the most outspoken of these was Yosaburō Takekoshi (1865-1950), a wel1known journalist and historian, 121 and a member of the Lower House of the Japanese Diet. He was singled out by the Dutch administration for close observation because of his unrelenting campaign urging not merely Japanese expansion, but actual seizure of the Netherlands East Indies. In books, articles, and speeches he argued that Japan held the key to a new order of civilization, and as such had a positive duty to bring enlightenment to those less privileged. In July 1905, he had written

Western nations have long believed that on their shoulders alone rested the responsibility of colonising the yet unopened portions of the globe and extending to the inhabitants the benefits of civilisation, but now we Japanese... . wish as a nation to take part in this great and glorious work. . . . As the Southern Cross seems to invite the mariner to investigate the wonders of the southern seas,

117V February 20, 1911, $\mathrm{L}^{4}$, Resident de Bruyn Kops to Gov. Gen., October 14, 1910. It does not appear that there was any Malay/English/Japanese dictionary published as early as 1911. Professor Shigeru Tsuchida, of the Tokyo Institute for the Study of Languages and Cultures of Asia and Africa, informs me that he located two guides to Malay in Japanese published in 1912, but neither are dictionaries, although they do include some word lists and phrases. Personal communication, May 26, 1976. Most of those Japanese interested in learning Malay were prospective rubber planters. In 1913, it was said that the demand was so great that a course set up by the Far East Asia Society (one of the Pan-Asiatic societies in Tokyo), accepted only eight pupils, and so had disappointed many applicants. V February 25, 1914, $\mathrm{C}^{4}$, Dutch Consul in Tokyo to Gov. Gen., August 26, 1913.

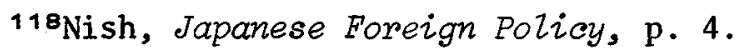

$1^{119}$ Antoine Cabaton, "Pays Malais," RMM, 23 (June 1913), pp. 128-29. Malay had been introduced at the University of London only two years before.

120 Professor Akira Nagazumi of Tokyo University to author, March 17, 1976.

${ }^{121}$ Takekoshi's magnum opus was The Economic Aspects of the History of the CiviZization of Japan, in three volumes (London: Allen and Unwin, 1930), but he also wrote a standard work called Japanese Rule in Formosa, trans. George Braithewaite (London: Longmans, Green and Company, 1907), and a biography of Prince Saionji

(Kyoto: Ritsumeikan University Press, 1933). 
so our successes in Formosa beckon us on to fulfil the great destiny that lies before us and make our country "Queen of the Pacific."122

Four years later Takekoshi visited the Netherlands Indies, and, upon his return to Japan, recorded his impressions in a book entitled Lands of the South (Nangoku-ki), which aroused such interest that there had been ten editions by October 1911.123 The Emperor, claimed Takekoshi, should stand as the savior of Asia, and Japan itself as the succor of a1l Asian races. The Netherlands was a tenth-rate power which could do nothing to help the people under its rule, and it was therefore Japan's responsibility to free the Malay race from its present miserable condition. "For there is little doubt that we have Malay blood in our veins. When I visited these islands, I felt as if I were travelling in Kyusshü, because the houses, the children, the fences around the houses, and everything in the life-style made me think of Japan."124

The kind of argument advanced by Takekoshi must have been particularly appealing to those Japanese actually residing in the Nanyo, and with business interests there. In 1913, the first Japanese newspaper in the archipelago was established in Singapore, entitled the Nanyo Nichi Nichi Shimbun (The South Seas Daily). It was closely monitored by the Dutch authorities, who were wary of an editorial line which urged Japanese expansion, especially to South Borneo and Sulawesi, and which, in the same vein as Takekoshi, discussed a possible annexation of the Netherlands Indies.125 Filtering down to Malays through conversations with Japanese shopkeepers and peddlers, 126 such articles, even

${ }^{122}$ Takekoshi, Japanese Rule in Formosa, pp. vii and 11.

${ }^{123} \mathrm{~A}$ pocket edition of this work appeared in January 1915 and at least 32 newspapers and 18 periodicals reviewed it, in most cases favorably. Professor Nagazumi to author, March 17, 1976. It was also translated into Chinese under the title Nan Kuo Chi, or the History of the Southern Kingdoms. V March 2, 1911, Dutch Consul at Seoul to Sir Edward Grey, December 1, 1910.

${ }^{124}$ Quoted in Java Bode, August 30, 1910, p. 2; "Japan Begerig naar Java en Sumatra," De Indische Gids, 38, 1 (1916), pp. 448-52. According to this argument, the Japanese were 30 percent Mongolian, 60 percent Malay, and 10 percent other stock. Similar claims became stronger in later years when Japan was actively promoting southern expansion. V February 25, 1914, $\mathrm{C}^{4}$, Adviser for Japanese and Chinese Affairs to Gov. Gen., August 26, 1913, and Mailrapport 1156, 1926, article from Jawa Nippō, November 4, 1921.

125Yuen, "Expansion of Japanese Interests," p. 19; V February 25, 1914, $\mathrm{C}^{4}$, Adviser for Japanese and Chinese Affairs to Gov. Gen., December 13, 1913.

$126 \mathrm{By} \mathrm{1914,} \mathrm{there} \mathrm{were} 38$ Japanese retail shops in Singapore, and the Controleur of Kerimun in the Riau Residency noted that the two resident medicine-sellers in his area had married Malay women and adopted Islam. Such people would certainly have been literate and at least in the urban centers would have had access to Japanese newspapers. Several writers on Japanese society have emphasized the widespread literacy in Japan and the influence of newspapers on public opinion. V March 28, 1914, $\mathrm{F}^{6}$, Controleur of Kerimun to Resident of Riau, December 24, 1913; Kee, "The Japanese in Malaya," p. 50; R. P. Dore, "The Legacy of Tokugawa Education," in Marius B. Jansen (ed.), Changing Japanese Attitudes toward Modernization (Princeton: Princeton University Press, 1969), pp. 102-3; Nish, Japanese Foreign Policy, pp. 84-85; Pyle, The New Generation, p. 82. 
in a distorted version, would have served to reinforce Japan's image as a nation that would drive out the foreigners and introduce the enlightened rule of a great Asian nation.

Developments in Riau

Since the end of the Russo-Japanese War, Indonesians, and particularly Moslem Indonesians, had been subject to an ever increasing amount of information about Japan, a combination of rumor, personal account, exhortation, and instruction. At the same time, within Japan itself, there was growing grass-roots support for a populist Pan-Asianism which would have Japan take a more militant stand against the colonial powers in the Nanyo. The impact of these developments in practical terms can. be seen if we turn again to Riau and examine events there immediately prior to the outbreak of World War I.

Though nothing had come of Riau's proposed appeal to Japan in 1905, it had not been forgotten. Meanwhile, the whole issue of the Yamtuan Muda position and the succession to the Riau throne smoldered, kept alight by constant reminders that the members of the Riau court were simply pensioned puppets. During this time the Sultan himself was drawn farther into what the Dutch called "the Bugis opposition party," and, according to the Resident, "the learned Raja Ali and Raja Hitam" now wielded great influence with the ruler. In their conversations with the Sultan, they constantly compared Riau's present situation with its past glory and impressed on him the view that he had surrendered not only his money but his prestige and self-respect to the Dutch.127 The frequency of clashes between court and administration lent weight to arguments that the Dutch should assume direct control over Riau-Lingga. In 1910, these disputes were brought to a head when the Sultan, on the advice of his ministers, refused to sign a new political contract, claiming that it would deprive him of any real authority. His adamancy provided the Dutch with sufficient cause for action, and in February of the following year he was formally deposed and exiled to Singapore.128 A few days after his arrival there, however, the ex-Sultan handed over copies of all treaties made between himself and the Dutch to the Japanese consul.129 On several occasions he met Japanese representatives privately, and he even sent a letter to the commander of the Japanese squadron in Singapore, whom he had previously entertained as a guest. ${ }^{130}$ Though Dutch agents were unable to

127V February 10, 1911, $Y^{3}$, Note by Resident de Bruyn Kops, December 28, 1910.

${ }^{128}$ For a Dutch explanation of their action, see the Nievwe Rotterdamsche Courant, February 11, 1911, Avondblad D, and Kielstra, "Nederland's Betrekkingen tot Riau," pp. 185-214.

${ }^{129}$ It is unlikely that the consul, who had been unsympathetic in his dealings with Sun Yat Sen, would have given Sultan Abdul Rahman more than a perfunctory hearing. He was later indirectly criticized by the Japanese newspaper in Singapore, the Nanyo Nichi Nichi Shimbun, because he had not taken the part of certain Japanese who had been arrested in Java for opium smuggling. See Jansen, The Japanese and Sun Yat Sen, p. 130; and Mailrapport 698, 1913, Adviser for Japanese and Chinese Affairs to Gov. Gen., March 24, 1913.

130V March 29, 1911, E7, Dutch Consul in Singapore to Gov. Gen., February 17, 1911 . 
discover the subject of these conversations and the letter, it was presumed that they concerned an appeal by the Sultan for Japanese intervention on his behalf. Large numbers of Riau Malays packed up their belongings and fled to Singapore in the belief that a great war was about to break out between the Dutch and Japan, with the possible intervention of Turkey.131

In Tokyo, the exile of the Riau Sultan provided ready fuel for the small band of Moslems and Pan-Asianists who wished to see greater Japanese involvement in the Nanyo. The Sultan of Riau had written what Resink describes as a unique letter to the Straits Times protesting against his deposition, $\mathbf{1 3 2}$ and his letter was reprinted in a journal called the Dai Tó (The Great East), the mouthpiece of the Ajia Gikai. This group, typical of a number of Pan-Asiatic societies in Japan, had been founded in 1910 and had the support of several prominent opposition politicians. The Dutch authorities believed that the Ajia Gikai had close links with the Japanese General Staff, and its pronouncements were therefore taken to be of some significance.133

The Sultan's letter, published in full, expressed his anger, and that of the Riau court, at the Dutch action; it went on to denounce the proposed treaty of 1910. He had refused to sign this treaty, he said, because it would have reduced him to the position of nominal ruler, depriving him of any power whatsoever. The only motive for his deposition, the Sultan claimed, was the Dutch desire to obtain the collection of "all the revenues, mining and other concessions."134

Accompanying this letter was an article written in English and entitled "Tyranny of the Dutch in the East Indies," which placed the deposition in a wider context of alleged anti-Moslem actions by the Dutch.

In its issue of February 15, 1911, our contemporary, the Straits Times of Singapore, contains the following letter which ought to serve as an eye-opener to all Moslem states that are rightly struggling to be free. The European powers that have dominion over Moslem lands are bound out of imperial considerations to use all possible means in preventing the regeneration of Moslem states. But the treatment accorded to Moslems in Java, Sumatra, and other East Indies [areas] by the Dutch government is the most atrocious in the annals of mankind. These Moslems are guarded like criminals, treated like brutes, forbidden to hold intercourse with the outside [world]. Since the Russo-Japanese war, ruler after ruler has been deposed by treachery on the part of the government. We advise our Moslem

131V Apri1 18, 1911, $\mathrm{S}^{8}$, Resident de Bruyn Kops to Gov. Gen., March 1, 1911.

${ }^{132} \mathrm{G}$. R. Resink, Indonesia's History between the Myths (The Hague: Van Hoeve, 1968), p. 95 .

133V January 30, 1912, Military Attache, Dept. of War, August 15, 1911, 74; De Locomotief, January 28, 1911. The politicians involved with the Ajia Gikai were said to be the Constitutional National Party leader Inukai Tsuyoshi (1855-1932), Kōno Hironaka (1849-1923), and the Pan-Asianist Toyama Mitsuru (1855-1944).

${ }^{134} \mathrm{Sultan}$ of Riau to Editor of Straits Times, February 15, 1911. 
brothers to strive after knowledge of the Koran and modern sciences, and despair not of divine assistance. ${ }^{135}$

A few months later, in April, the journal of the newly established Tokyo Islamic Brotherhood, which was headed by a British Indian and devoted to promoting the image of Japan in Moslem countries, also published an article describing colonial rule in the Indies. Dutch officials were convinced that the writer, who signed himself "Anonymous" of Johor Bahru, was actually one of the exiled members of the Riau royal family. The Dutch intelligence system was highly efficient, and the suspicion was probably correct. Regardless of its origin, the description of Dutch rule by this unknown author conveys some idea of the bitterness felt by the Riau court. Two hundred and fifty years of colonial oppression, he wrote, had brought the once mighty kingdoms of the Indies to their knees. The greatest Dutch crime, however, was their prohibition of "the entrance of teachers of Islam and learned men of the religion," and their indifference to the fact that the people they governed "are a noble race among the descendants of Adam, intellectually and morally. They possess, like other people, great capacity to progress if the circumstances would permit and teachers be forthcoming."

Appealing to Japanese readers, the writer went on to repeat the claims put forward by men like Takekoshi. Those now suffering under Dutch rule "belong to the same stock that the Japanese do, as the similarity of their features and customs testifies."136

The Riau court was not satisfied, however, with simply sending letters to foreign journals, and there can be no doubt that the princes were determined to fight for the reinstatement of the sultanate. In August 1911, Sultan Abdul Rahman wrote personally to Queen Wilhelmina, begging for her mediation so that "I will not end my days as an exile, in shame and humiliation." He even announced his willingness to step aside in favor of his young grandson, if the latter would be more acceptable as a future ruler.137 The Dutch rejection of this proposal, the establishment of direct European government in Riau, and the ignominious banishment of the foremost princes, were regarded by the court as outrageous. It was unthinkable that descendants of a dynasty which had ruled for two hundred years could be swept aside in such a fashion. What was obviously needed was a powerful patron willing to stand with Riau against the colonial administration. Faced with a similar situa-

135V January 30, 1912, Military Attache, extract from Dai To, February 1911. The letter also appeared in a book by a university economist, Inouye Kijoshi, entitled Nanyo to Nihon (The Southern Pacific and Japan), published in Tokyo in 1913, pp. 114-24. I am grateful to Mr. Akira Oki of the Department of Pacific and Southeast Asian History, Australian National University, for this reference.

${ }^{136} \mathrm{~V}$ November 4, 1911, Gov. Sec. to Gov. Gen., September 18, 1911. The founder of the Islamic Brotherhood, Hassan Hatano, was associated with Indian nationalists. ANA A2219 (Secret Abstracts of Intelligence, General Staff, Straits Settlements) 4/18, 96. The journal was published in English, but had a monthly Japanese supplement. "Revue de la presse musulmane," RMM, 25 (December 1913), p. 382.

137V April 18, 1911, $\mathrm{S}^{8}$, Resident de Bruyn Kops to Gov. Gen., March 1, 1911; V October 21, 1911, 33, Sultan of Riau to Queen Wilhelmina, received August 20, 1911, fo. 11 . 
tion eight years before, Raja $A 1 i$ and his following had seen their natural protector in the Raja Rūm, but they now understood, if only vaguely, that since 1908 the ottoman Sultan had relinquished his authority to a group of modernizing reformers, who were themselves hard pressed by Italy and the Balkan allies (Serbia, Greece, Albania, and Bulgaria).138 There was virtually no likelihood that help of any material nature would be forthcoming from Turkey at this point, and to expect assistance from any European power, such as England, was clearly futile.139 As in 1905, it seemed that Japan was the only possible source of aid, but this time there would be no preliminaries with minor officials; this time Riau would send an appeal directly to the Japanese Emperor himself. In September 1912, nearly two years after the Sultan's deposition, the indefatigable Raja Hitam was reported to be collecting money from Riau residents visiting Singapore to finance a trip to Japan, and plans were also afoot to extend his campaign throughout the Riau archipelago.140

Raja Hitam was sufficiently astute to realize that any such collection could not be made openly, since it would certainly arouse Dutch opposition and mean protests to the Singapore government. Instead, he set up a Malay trading cooperative in Singapore which sold copra directly, rather than through Chinese businessmen as was customary. The majority of the members came from the copra-rich pulau Tujuh area, and their subscription fee of $\$ 100$ (Singapore) was incorporated into Raja Hitam's funds for the trip to Japan.141 When this venture failed, Raja Hitam turned to other means of obtaining money. Documents were drawn up for land ownership in preparation for the Japanese administration which, villagers were assured, would take over when Riau's case was presented personal1y to the Emperor. Apparent legitimacy was given to these claims by Raja Hitam's agents, two haji and a Japanese medicineseller, who traveled to remote islands informing the inhabitants that the Sultanate would soon be restored and that only these new documents, available for $\$ 15$ (Singapore), would then be acceptable proof of land

${ }^{138}$ See Berkes, The Development of SecuZarism in Turkey, pp. $269 \mathrm{ff}$. for a discussion of the secular aspects of the Young Turk movement. Resident de Bruyn Kops said he had discussed the new administration in the Turkish government with Raja Ali and Raja Hitam in order to point out the advantages of such changes. V February 10, $1911, Y^{3}$, note by Resident de Bruyn Kops, December 28,1910 , fo. 20 . The ItaloTurkish war of 1912 had also aroused great interest in Singapore, where collections were made to support the Turkish forces. V November 2, 1912, 20/2373, Adviser for Native Affairs to Gov. Gen., April 4, 1912; Tan, "The Life and Times of Sayyid Shaykh," p. 43.

${ }^{139}$ The Governor of the Straits Settlements informed the Dutch consul that the ex-Sultan of Riau, whom he described as "a harmless old man," had come to pay his respects. "I said I was sorry that he had quarrelled with the authorities and suggested to him that he should go to Batavia and endeavor to see the Governor General and try and come to some arrangement. . . He thanked me for my advice, but I doubt if he will follow it." V April 18, 1911, $\mathrm{S}^{8}$, Sir John Anderson to Dutch Consul in Singapore, March 7, 1911.

${ }^{140} \mathrm{~V}$ July 21, 1913, 5, Dutch Consul in Singapore to Resident de Bruyn Kops, September 16, 1912 .

141V April 12, 1913, 15, Civiele Gezaghebber at Pulau Tujuh to Resident de Bruyn Kops, February 6, 1913. 
ownership. 142 Money was also collected under the guise of sedekah, or alms, from the Riau pilgrims lodging in Singapore, while several members of the exiled royal family, now living in Singapore and Johor, contributed funds from the sale of their personal belongings.143

The decision to send a mission to Japan was thus not an independent and unsupported move by a few individuals. The Riau nobles clear$1 y$ anticipated success. They may on this occasion have received specific encouragement from a Singapore acquaintance of Raja Hitam, a Japanese doctor named Arito Sato,, who had once been entertained in the Penyengat istana (palace) and to whom Raja Ali had rented concessions on several islands.144 Another factor contributing to the genera1 optimism was probably the presence in Tokyo of a Penyengat man, Encik Ahmad, a friend of Raja Ali and son-in-law of Johor's Menteri Besar. According to Dutch reports, Encik Ahmad was employed as a Malay teacher at the Tokyo School for Foreign Languages, and prior to his departure from Singapore he had received a visit from the ex-Sultan of Riau.145 But even without such encouragement the Riau nobles had, over the years, been led to believe that the Japanese government would lend a sympathetic ear to pleas for help; accordingly, sometime in october 1912, a letter was drawn up asking for the Emperor's personal intervention so that Riau could be placed under Japanese rule and the Sultan restored to his former position. 146

On October 31, Raja Hitam left for Tokyo, carrying with him the Riau petition signed by the Sultan and his advisers. Among his countrymen rumors spread wildly. Dutch spies heard that Raja Hitam would become a naturalized Japanese citizen in order to enter Riau secretly; the Singapore consul informed Batavia that an officer from the Japanese flagship Kongo, then docked in Singapore, had reportedly been seen charting islands in the Riau archipelago. A German source in St. Petersburg even relayed the information that Japan planned to buy Riau from the Dutch! 147

142Ibid., and V July 21, 1913, 5, Resident de Bruyn Kops to Gov. Gen., April 29, 1913. Raja Hitam received very little support from people in the Pulau Tujuh group, possibly because they lived so far from the central administrative districts and thus for them the Sultan was only a vague figure. The haji concerned were jailed, and the money, amounting to $\$ 1,000$ (Singapore), confiscated and returned to those who had bought the false documents. Mailrapport 1405, 1914, "Memorie van Overgave" by Resident de Bruyn Kops, March 3, 1914.

${ }^{143}$ As above, $\mathrm{n} .136$, and V April 12, 1913, 15, Resident de Bruyn Kops to Gov. Gen., February 18, 1913.

${ }^{144} \mathrm{~V}$ July 9, 1914, 45, Resident Veenhuyzen to Gov. Gen., May 10, 1914. Satō had also made some 1 and purchases in Kota Waringin, where there had been similar attempts to appeal to the Japanese government. See above, n. 82 .

145V March 29, 1913, 26, Dutch Envoy in Tokyo to Gov. Gen., December 27, 1912; V July 21, 1913, 5, Dutch Consul in Singapore to Resident de Bruyn Kops, September $16,1912$. 1912.

146V January 13, 1913, 63, Resident de Bruyn Kops to Gov. Gen., November 7,

147Ibid., Minister of Foreign Affairs to Minister of Colonies, January 3, 1913; V March 29, 1913, 26, Dutch Consul in Singapore to Dutch Envoy in Tokyo, January 20, 1913; V January 30, 1913, f, Resident de Bruyn Kops to Gov. Gen., November 21, 1912; 
Meanwhile, on arriving in Tokyo, Raja Hitam had gone directly to Encik Ahmad's house, assuming an alias to avoid detection by the Dutch. He was not successful, however, in escaping the eagle eye of the Dutch intelligence system. The consul in Tokyo was soon able to confirm not only that Raja Hitam had arrived, but that he had left Japan after a few days, returning to Singapore via Yokohama. ${ }^{148}$ Lacking information from those involved, it is difficult to ascertain the reasons behind Raja Hitam's precipitate departure. He may have been influenced by Encik Ahmad's unfavorable opinion of the Japanese and his argument that the Riau court was too optimistic in its hopes for Japanese assistance. When interviewed by Dutch agents, Encik Ahmad only explained that his friend had left quickly because "very little happened here, and he found it too cold."149 Nonetheless, despite this disappointment, the Riau princes' belief that a personal audience with the Emperor would surely result in Japanese aid appeared unshaken. In April 1913, shortly after his return, Raja Hitam and several of the exiled princes were said to be again collecting money to finance a trip to Japan, 150 and once more the rumors of an imminent restoration of the Sultanate sprang up. 151 During the ensuing months, repeated meetings were held in Singapore among a group which included the Menteri Besar of Johor (Encik Ahmad's father-in-1aw), Raja Hitam, and other members of the Riau court. For a time there was even talk that the Menteri Besar himself might accompany Raja Hitam to Japan, presumably in the belief that this eminent personage would facilitate access to the Emperor's presence.152 Raja Ali and his friend of al-Imam days, Sayyid Shaykh a1-Hadi, were also active fund raisers. In May 1913, they made a trip to British-controlled Trengganu to collect money and solicit the support of the Trengganu ruler, while the ex-Sultan of Riau personally contributed three thousand Straits dollars towards the endeavor. 153

The following June another meeting was held in Johor at which it was decided that Raja Hitam and Raja Ali should leave for Japan as soon as the necessary money had been raised, taking with them the deeds to thirty plots of coconuts contributed by Riau Malays as a gift in return

V February 25, 1914, $\mathrm{C}^{4}$, Dutch Consul in Singapore to Gov. Gen., November 20, 1913, and De Bruyn Kops to Gov. Gen., December 1, 1913.

148V June 11, 1913, Dutch Envoy in Tokyo to Gov. Gen., March 31, 1913.

149 Ibid., and V April 15, 1914, 27, "Verslag van een onderhoud met Raja Hitam," by a Majoor van den Generalen Staf, January 19, 1914 .

${ }^{150}$ Ibid., Dutch Vice-Consul in Singapore to Gov. Gen., April 8, 1913.

$151 \mathrm{~V}$ July 21, 1913, Resident de Bruyn Kops to Gov. Gen., April 29, 1913.

152V July 26, 1913, 13, Dutch Vice-Consul in Singapore to Gov. Gen., May 14, 1913. Datuk Abdullah bin Mohammad of Johor Baharu considers it unlikely that the Menteri Besar of Johor, Datuk Ja'afar bin Haji Mohd. (born 1837) would have been personally involved in Raja Hitam's adventures, although the family connections between Riau and Johor were very close. Personal communication, May 25, 1976.

153V August 9, 1913, Dutch Vice-Consul in Singapore to Gov. Gen., May 30, 1913; V September 15, 1913, Vice-Consul of Singapore to Gov. Gen., June 25, 1913. For a discussion of Riau's relations with Trengganu, see J. de Vere Allen, "The Ancien Régime in Trengganu, 1909-1919," JMBRAS, 41, 1 (1968), pp. 38-46. 
for Japanese assistance. ${ }^{154}$ On December 11, Raja Hitam 1eft, again alone, since Raja Ali had taken up the position of Ketua Agama (religious head) in Johor and could not leave his post. 155 But after all this effort and planning, the results were less than nothing. On March 11, 1914, after a brief period in a Japanese hospital, Raja Hitam died, apparently succumbing to the bitter cold of Tokyo's winter.156 Among his papers were found correspondence between the Riau Resident and the Sultan, the court's finance books for 1911 and 1912, and copies of notes concerning the sale of certain areas in Riau to Japanese. Among these, the Dutch consul could find "no facts of interest to the government," and as far as the Netherlands Indies authorities were concerned, the matter was closed. 157

\section{Conclusion}

With the outbreak of the Great War in August 1914 and the traumatic events of the next five years, the affairs of Riau sank into insignificance, even for the Dutch. Though Japan was clearly more interested in the Nanyō than before, it was now absorbed by power politics on a grand scale, and another decade was to pass before the Japanese government began to think seriously about southward expansion and consider the possibility of exploiting Islam as a political tool.158 Despite the hopes raised by the Japanese victory over Russia and the urging of successive Japanese politicians and nationalists, there was at no time any real likelihood of a confrontation between Japan and the colonial nations in the Southern Seas. The concept of a Japan-led "Greater Asia" had its attractions, but official Japanese policy was essentially to gain acceptance as a modern, Westernized power. As the Japanese consul in Australia wrote in 1905, "Our claim... is for recognition of our equal status with European nations in the numerous things which are comprised in the term 'civilisation.'"159 Japanese delegations to European conferences might continue to press for the elimination of racial inequality, but in Singapore in 1915 Japanese sailors as well as about 100 Japanese nationals played a crucial role in assisting the ill-prepared British to suppress a mutiny among Indian sepoys.160 A few months later a member of the Lower House of the $25,1913$.

${ }^{154} \mathrm{~V}$ September 15, 1913, 52, Dutch Vice-Consul in Singapore to Gov. Gen., June

155V January 26, 1914, 62, Gov. Secretary to Dutch Consul in Singapore, December 11, 1913; V February 20, 1914, Dutch Consul in Singapore to Gov. Gen., December 20, 1913. Because of Dutch pressure, Raja Ali was deprived of his position later that year. He died about 1919. Allen, "The Ancien Régime," p. 40 n. 79; Tan, "The Life and Times of Sayyid Shaykh," p. 43.

156V April 15, 1914, 27, Tokyo Envoy to Gov. Gen., March 14, 1914.

157V July 9, 1914, 45, Resident Veenhuyzen to Gov. Gen., May 10, 1914.

${ }^{158}$ Harry J. Benda, The Crescent and the Rising Sun (The Hague: Van Hoeve, 1958), pp. 103-5.

${ }^{159}$ ANA A2219, I, Japanese Consul in Australia to Attlee Hunt, September 20, 1905.

160Yuen, "Expansion of Japanese Interests," p. 115. 
Japanese Diet publicly protested that it was "truly outrageous" for Japanese to be treated "identically with Chinese and Indians."161

Such comments raise the question of why the Riau court continued to believe in what one Dutch resident called "the fiction of a good relationship between the Sultan's party and Japan."162 In objective terms it is obvious that there was never even a remote chance of Japanese interference in Riau. On what, then, was the faith of the Riau princes based? There is no indication that they had any connection with the Western-educated Indonesians who were lauding Japanese success, and with whom they would have had little in common.163 Across the Straits in Johor, neither Abu Bakar nor his son Sultan Ibrahim attempted to exploit their contacts with Japan in dealing with the British, despite their admiration of things Japanese.164 Nor can Riau's expectations of Japan be seen as part of the nationalist mood discernible elsewhere in Asia. The Sultan and his advisers, though aware of what was happening in, for example, China and India,165 did not want "independence" as such; themselves militarily and diplomatically powerless, they saw acceptance of Japanese suzerainty as the only means of evicting the Dutch.

The tenacity of the assumption that Japan would be willing to take up the Riau cause is perhaps more readily understood by recalling the sources of most of Riau's ideas about Japan and by considering the manner in which Malays had traditionally gained information concerning notable events in the world. Prior to the nineteenth century, the most reputable news was that carried by itinerant scholars and teachers from the Middle East who, traveling between religious centers like Aceh, Riau, and Palembang, brought the opinions and pronouncements of Islam's heartland to the notice of the Malay courts. During the course of the nineteenth century, as access to the Middle East became easier and communication more rapid, this network, essentially oral, expanded and developed through the written word to encompass the entire Moslem community. But while media such as newspapers and telegraph were innovations, the origins of the issues they discussed were quite traditional; emanating from the foremost spokesmen of Islam, articulated in the Prophet's own tongue, they commanded the attention of Moslems everywhere.

${ }^{161}$ ANA A2219, I, External Affairs, 11305, February 5, 1916.

162Mailrapport 1405, 1914, "Memorie van Overgave" by Resident de Bruyn Kops, March 3, 1914, fo. 237.

163Among the Riau princes only Sultan Abdul Rahman's three sons had had any European education. They had spent about eighteen months at the hoofdenschool in Bandung but returned to Riau because of illness, and then continued their education in Cairo. Nieuwe Rotterdamsche Courant, September 18, 1901, p. 1; V October 6, 1905, 54, Egyptian Under Sec. of State to Dutch Consul in Cairo, December 22, 1904.

164 Among the Johor elite prior to World War II, Sultan Ibrahim looked to London to balance Singapore, and the nobles who opposed him looked to the British to balance the Sultan. Mr. Christopher Gray of Yale University to author, April 6, 1977.

${ }^{165}$ The movements for independence in a number of countries had been discussed in al-Imam. See, for example, 2, 2 (August 10, 1907), p. 59. 
For nearly a hundred years Islamic society had debated the issue of its backwardness in relation to the Christian West. and its lack of so much that was subsumed under the Western notion of civilization. "Civilization" meant modernity and might, and in that sense was desirable; but would the emulation of infidels which it entailed ultimately result in the corruption of Islamic morals by Christian or secular influences? Was the superiority of the West so great that it was destined to maintain its dominance forever? The achievement of Japan had provided the answer to Islam's dilemma. Japan was now deemed "civilized"--yet it had not surrendered itself to alien values or customs. By its example it had earned the right to become the mentor of all Asians, and especially those of the Moslem faith. This was the authoritative message which for more than a decade had been transmitted to Riau via its links with the great Islamic centers of the Middle East. Sanctioned by the authority of religion, the claims of Japan's readiness to defend its fellow Easterners against the Westerners assumed a greater credibility, shoring up the hope that under the Japanese umbrella the infidels would be evicted, the old order reinstated, and the country opened up to the ilmu that would restore Riau's lost prestige. 